UNIVERSIDADE DE BRASÍLIA

FACULDADE DE DIREITO

PATRICIA MIRANDA BORNHAUSEN CARDOSO

\title{
A RESPONSABILIDADE CIVIL MÉDICA NA CIRURGIA PLÁSTICA ESTÉTICA
}

BRASÍLIA

2009 


\section{A RESPONSABILIDADE CIVIL MÉDICA NA CIRURGIA PLÁSTICA ESTÉTICA}

Monografia apresentada como requisito para conclusão do Curso de Bacharelado em Direito da Faculdade de Direito da Universidade de Brasília (UNB).

Orientador: Dr. Paulo Roberto Binicheski

BRASÍLIA 


\section{A RESPONSABILIDADE CIVIL MÉDICA NA CIRURGIA PLÁSTICA ESTÉTICA}

Monografia apresentada como requisito para conclusão do Curso de Bacharelado em Direito da Faculdade de Direito da Universidade de Brasília (UNB).

Orientador: Dr. Paulo Roberto Binicheski

Área de Concentração:

Data de Defesa:

Resultado:

BANCA EXAMINADORA

Dr. Paulo Roberto Binicheski - Orientador

Dra $^{\mathrm{a}}$. Ana Frazão de Azevedo Lopes - Prof ${ }^{\mathrm{a}}$ da Faculdade de Direito - UNB

Dr. Frederico Henrique Viegas de Lima - Prof $^{\circ}$. da Faculdade de Direito - UNB 
Dedico este trabalho aos meus familiares, que muito me incentivaram, me dando forças para lutar pelos meus objetivos. Agradeço ao professor orientador, Dr. Paulo Roberto Binicheski, pelo tempo dedicado e pelos seus ensinamentos. 


\section{RESUMO}

A cirurgia plástica estética, nos dias atuais, deixou de ser vista como vaidade e sim uma necessidade para o bem estar na sociedade e na vida profissional. É muito importante que as pessoas tenham consciência de que uma cirurgia plástica, antes de ter fins estéticos, é uma cirurgia como outra qualquer. Por esse motivo, ela envolve uma decisão do paciente em conjunto com seu médico que avaliará todo o histórico e indicará o melhor procedimento. $\mathrm{O}$ paciente deve procurar conhecer os riscos a que estará exposto, independentemente da qualidade do profissional. Diante dessa necessidade, paira a responsabilidade civil, imprescindível ao bem comum e ao progresso social. No entanto, para que ela seja caracterizada, faz-se necessária uma conduta culposa, um nexo de causalidade e um prejuízo ou dano: moral, material ou estético. A cirurgia estética está relacionada com a reestruturação ou moldagem do contorno corporal para melhorar a aparência, ou seja, não há uma doença física relacionada. Já a cirurgia reparadora visa reparar anormalidades ocasionadas por doenças congênitas, traumas, queimaduras, infecções e tumores. Assim, em geral, as cirurgias têm a finalidade de reparar a função, mas podem ser realizadas para melhorar o aspecto físico. A tentativa de divisão entre estes dois ramos da cirurgia é apenas teórica, no entanto, muito utilizada atualmente para a definição de determinadas relações comerciais. Quando um paciente se submete a uma cirurgia estética ou reparadora, espera resultados que por vezes não são satisfatórios. Surge então um impasse, de quem é a responsabilidade ou qual é a obrigação assumida pelo profissional de medicina, se de meio ou de resultado. Portanto, buscar-se-á neste trabalho uma análise jurídica face aos trabalhos dos médicos que atuam em cirurgias plásticas estéticas.

Palavras-chave: Responsabilidade civil. Cirurgias plásticas estéticas. Obrigação de meio. Obrigação de resultado. 


\begin{abstract}
Nowadays, aesthetic plastic surgery is no longer seen as vanity, but as a necessity for a person's social and professional well-being. It is very important that people are aware that a plastic surgery, even though done for an aesthetics purpose, is just like any other surgery. For this reason, the decision involves both the patient and his or her doctor, who must first analyze all the medical history in order to choose the best procedure. The patient must learn all risks to which he or she will be subjected, independent of the reputation of the plastic surgeon. Knowing this necessity, the essential of the common good and social progress dictates civil liability. However, in order for this liability to be created, it is necessary to have a malicious conduct, a causal connection, and damage, whether physical or emotional. Aesthetic surgery is related to the restructuring or molding of the body shape to improve one's appearance; in other words, there is no physical illness involved. The reconstructive surgery, on the other hand, has as a goal repairing abnormalities caused by congenital illnesses, traumas, burns, infections and tumors. Thus, in general, all surgeries have the purpose of repairing a function, and in some cases, also improve the physical characteristics. The attempt to divide these two branches of the surgery is only theoretical; however, it has been recently common to use these branches to identify potential patients. When a patient undergoes aesthetic or reconstructive surgery, he or she is sometimes dissatisfied with the obtained results. A question then arises: what obligations or responsibilities are imposed on the plastic surgeon? Does one look to how the surgery was performed or to the results achieved? Therefore, this project will conduct a legal analysis of the performance of aesthetic plastic surgeons.
\end{abstract}

Key-words: Civil liability. Aesthetic plastic surgeries. Liability in execution. Liability for result. 


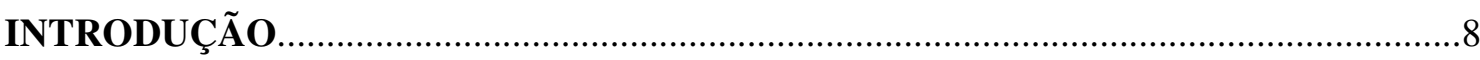

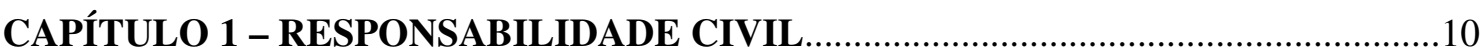

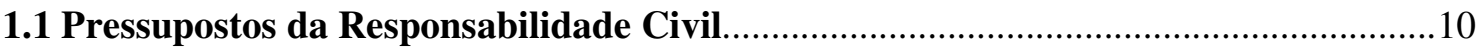

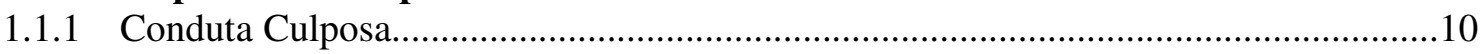

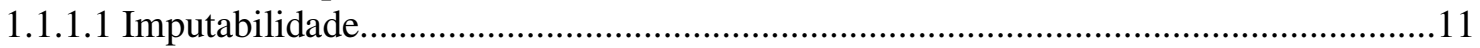

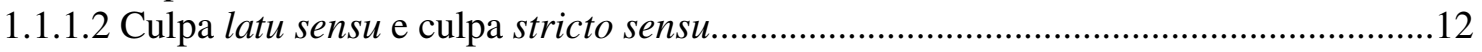

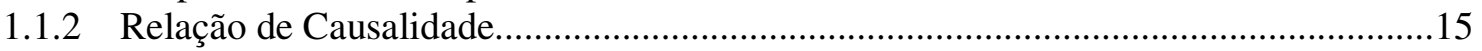

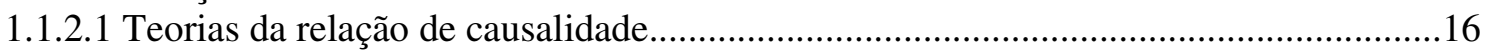

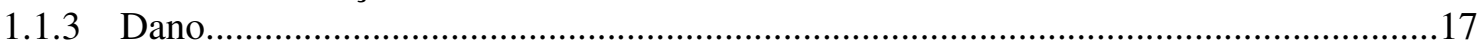

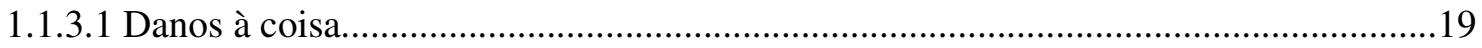

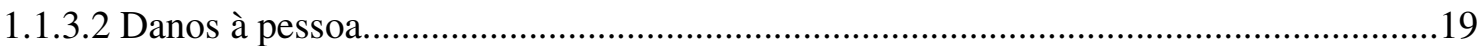

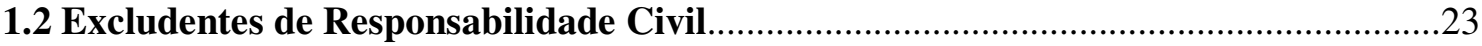

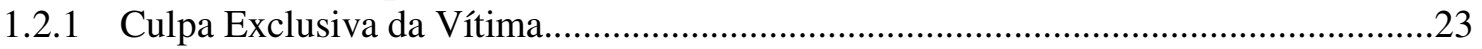

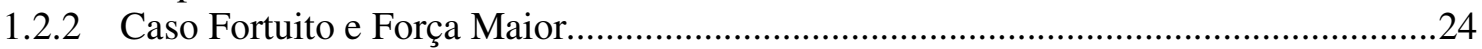

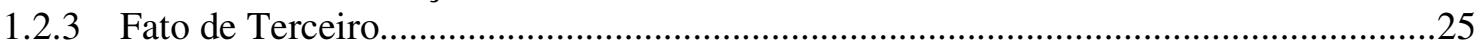

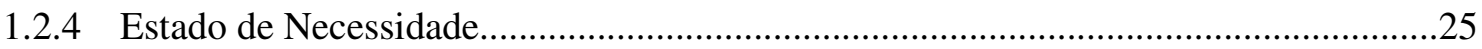

1.2.5 Legítima Defesa, Exercício Regular do Direito e Estrito Cumprimento do Dever

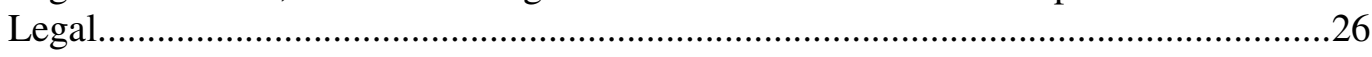

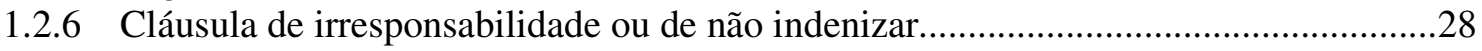

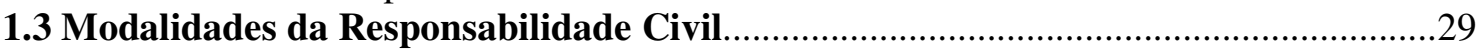

1.3.1 Responsabilidade Penal e Civil e Disciplinar...........................................................29

1.3.2 Responsabilidade Contratual e Extracontratual...........................................................

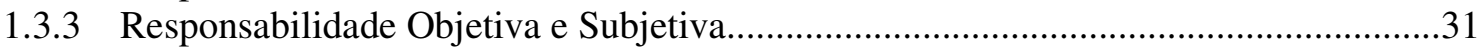

CAPÍTULO 2 - RESPONSABILIDADE CIVIL DO MÉDICO....................................33

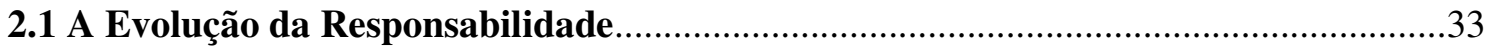

Eneas. Dano Moral e Dano Estético. Rio de Janeiro: Renovar, 2008, p. 111.

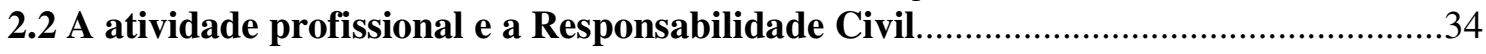

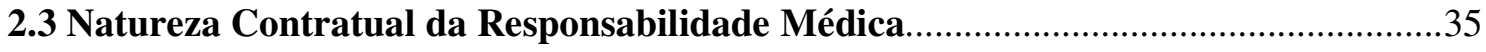

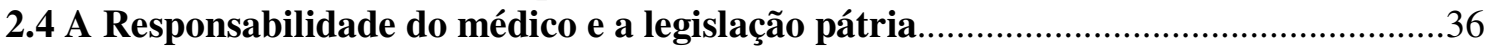

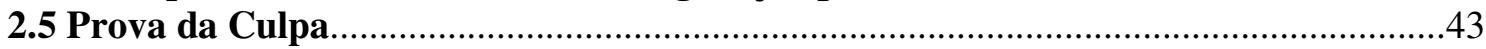

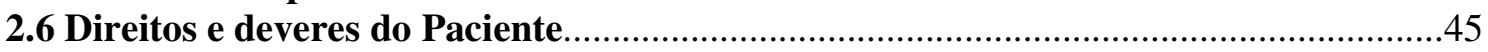

2.6.1 Dever de informação e obtenção de consentimento..................................................47

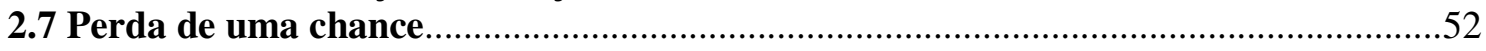

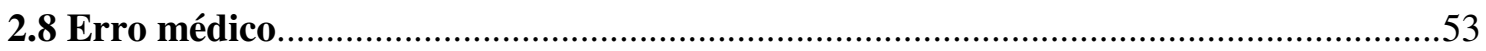

2.9 Responsabilidade da equipe cirúrgica e erro anestésico........................................56

CAPÍTULO 3 - RESPONSABILIDADE CIVIL NAS CIRURGIAS PLÁSTICAS

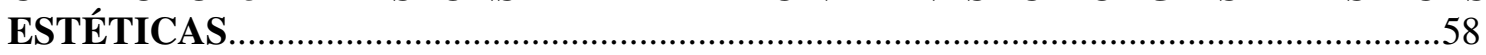

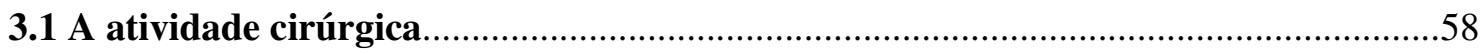

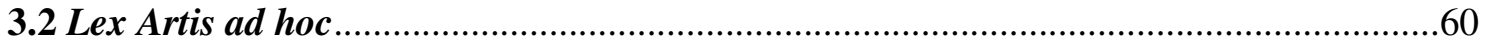

3.3 Cirurgia Plástica estética: Obrigação de Meio ou de Resultado.................................61

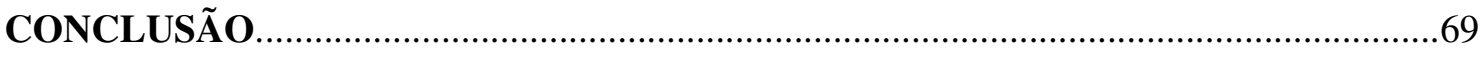

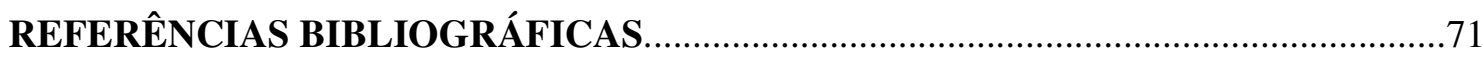




\section{Introdução}

No Brasil, por ser um país de clima tropical, a exposição do corpo é muito grande. Assim, em nome da estética corporal imposta pela sociedade, a procura pelas cirurgias plásticas está aumentando cada vez mais.

Verificamos que, todos procuram não só viver muitos anos, mas viver bem, o que pode se dar através de uma boa alimentação, viagens e cuidados com a aparência. A cirurgia plástica estética surge aí para auxiliar na correção de alguns defeitos externos que proporcionam um mal-estar físico, psíquico e moral.

No entanto, algumas pessoas buscam através da cirurgia plástica um resultado incomum, por vez inatingível, em decorrência das características do próprio corpo, como o tipo e cor de pele e o biótipo, que estão além da capacidade humana. Por esta razão, cabe ao médico, como profissional liberal, alertar aos pacientes sobre essas possíveis reações inesperadas e expor as chances de êxito, levando em consideração que na cirurgia plástica estética existem riscos como qualquer outra cirurgia.

A escolha do cirurgião deve ser feita com muito cuidado, verificando, se o médico é especializado em cirurgia plástica e se está associado à Sociedade Brasileira de Cirurgia Plástica (SBPC). Tal cuidado é necessário porque os profissionais dessa área estão se multiplicando cada vez mais, e o que se verifica é uma ausência de técnica, preços baixos e condições péssimas para a realização da cirurgia.

Outro aspecto a considerar é que, em muitos casos, há uma propaganda enganosa, em que se promete um resultado inalcançável, o que faz com que os pacientes saiam insatisfeitos da intervenção cirúrgica e busquem de algum modo a reparação de sua frustração. Por esta razão, faz-se necessária a distinção da obrigação de meio e de resultado dos médicos, a fim de se estabelecer as consequências a serem advindas em caso de insucesso, visto que, com o aumento significante de erros médicos e a complexidade do assunto, os juízes e doutrinadores seguem caminhos diferentes.

Primeiramente, o presente estudo abordará alguns princípios do instituto da Responsabilidade Civil, tais como, os pressupostos a serem identificados para que o agente venha a responder pelo dano causado. Em seguida, serão apresentadas as excludentes de responsabilidades que, caso comprovado, poderão eximir os médicos do dever de indenização 
e, as diferenças entre responsabilidade penal, civil, disciplinar e, responsabilidade subjetiva e objetiva.

No segundo capítulo, serão analisados alguns aspectos fundamentais sobre a responsabilidade civil dos médicos, como a natureza contratual entre o médico e o paciente, o erro médico, a prova da culpa e os direitos e deveres de cada um nessa relação contratual. Assim, como a cirurgia plástica estética é uma intervenção cirúrgica com um alto grau de complexidade e não emergencial, um dos deveres principais do médico é informar claramente o tratamento adequado e o prognóstico, além de agir com diligência e seguir todas as regras da sua profissão.

Por fim, no terceiro capítulo, realizar-se-á uma breve distinção entre as cirurgias plásticas reparadoras e estéticas e, logo em seguida, serão abordados os aspectos relativos à própria cirurgia plástica estética, no qual alguns doutrinadores a enquadram na responsabilidade de meio, em que cabe ao médico agir com cautela e prudência, não sendo necessário atingir o resultado esperado pela vítima. Portanto, o médico, neste caso, só responderia em caso de culpa.

No entanto, há quem afirme que se está diante de uma responsabilidade de resultado, até porque, ninguém se submeteria a uma intervenção cirúrgica se não fosse para atingir o resultado assumido pelo médico contratualmente. Assim, o médico deveria ser responsabilizado independentemente de averiguação de culpa.

A fim de tentar solucionar esse impasse, foram utilizadas, na presente monografia, pesquisas bibliográficas (através de livros e periódicos de autores renomados no mundo jurídico) e jurisprudências (como os julgados do Superior Tribunal de Justiça, Tribunais de Justiça Estaduais). 


\section{CAPÍTULO 1 - RESPONSABILIDADE CIVIL}

\subsection{Pressupostos da Responsabilidade Civil}

A Responsabilidade Civil consiste "na obrigação que se impõe à determinada pessoa de reparar os prejuízos causados a outra em razão de certo comportamento"1. E para que surja esse dever de responsabilizar o profissional de medicina, faz-se necessário a identificação de alguns pressupostos, como a conduta humana culposa, a relação de causalidade e o dano.

\subsubsection{Conduta Culposa}

O primeiro pressuposto é a conduta culposa. Neste sentido afirma Rui Stoco que: "o elemento primário de todo ilícito é uma conduta humana e voluntária no mundo exterior"2. Essa conduta pode se dar de forma positiva, através da ação ou negativa, em que se caracteriza a omissão. Assim, por ação podemos entender como a exteriorização de uma conduta, como a lesão corporal causada a outrem e, por esta razão, o agente não pode ser responsabilizado pelo simples pensamento, planejamento ou cogitação.

Já na omissão, verificamos a abstenção de uma conduta devida, contribuindo, desta forma, para a ocorrência do evento danoso. Todavia, essa questão só tem relevância quando o agente tem o dever jurídico de agir, de impedir o resultado e nada o fez. Esse dever pode decorrer de lei, convenção, como o dever de guarda, ou até mesmo criação de uma situação de perigo.

Além disso, para que o agente assuma o dever de reparação, não basta a violação do direito de um terceiro ou a infração de uma norma jurídica, na medida em que é preciso que o agente tenha agido com culpa, conforme o Código Civil de 2002:

Art. 186. Aquele que, por ação ou omissão voluntária, negligência ou imprudência, violar direito e causar dano a outrem, ainda que exclusivamente moral, comete ato ilícito.

\footnotetext{
${ }^{1}$ SAMPAIO, Rogério Marrone de Castro. Direito civil: responsabilidade civil. São Paulo: Atlas. 2000, p. 29.

${ }^{2}$ STOCO, Rui. Responsabilidade civil e sua interpretação jurisprudencial: doutrina e jurisprudência. 3. ed., São Paulo: Revista dos Tribunais, 1997, p. 54.
} 
Assim, a conduta culposa surge a partir do dano causado à vítima em razão de ausência de diligência do agente, ou seja, o fim a que se destina essa conduta é lícito, mas não há observância do dever de cuidado. Neste caso, o médico deverá responder pelos seus atos desde que o resultado possa ser previsto e evitado, de acordo com Rosana Jane Magrini ${ }^{3}$.

\subsubsection{Imputabilidade}

Como foi visto, para que o agente seja responsabilizado civilmente, a conduta do agente deve ser culpável, o que requer capacidade de discernimento e autodeterminação do agente. A isto, dá-se o nome de imputabilidade.

A imputabilidade nada mais é do que o conjunto de condições que permitem que o agente responda por seus atos reprováveis. Assim, dois são os elementos da imputabilidade: a maturidade e a sanidade mental.

De acordo com o art. $3^{\circ}$, I, do Código Civil, os menores de 16 (dezesseis) anos não são responsáveis em razão de sua incapacidade, devendo responder por eles os pais, enquanto estiverem sob sua autoridade e sua companhia (Art. 932, I, do Código Civil). E quanto às obrigações dos relativamente incapazes (entre 16 e 18 anos), o Código Civil de 2002 não faz menção, o que diferencia do Código Civil de 1916, que em seu art. 156, equiparava-os com os maiores de idade.

No entanto, o Estatuto da Criança e do Adolescente (Lei 8.069/1990), dispõe em seu art. 116 que quando se tratar de danos materiais, "a autoridade poderá determinar, se for o caso, que o adolescente restitua a coisa, promova o ressarcimento do dano, ou, por outra forma, compense o prejuízo da vítima", devendo entender como adolescente, a pessoa entre 12 a 18 anos de idade, conforme o art. $2^{\circ}$ do referido Estatuto.

Nesse mesmo sentido, a Jornada de Direito Civil elaborada pelo Centro de Estudos Judiciários do Conselho da Justiça Federal em setembro de 2002, em Brasília, aprovou o Enunciado n 40 que afirma que: "o incapaz responde pelos prejuízos que causar de maneira subsidiária ou excepcionalmente, como devedor principal, na hipótese do ressarcimento

\footnotetext{
${ }^{3}$ MAGRINI, Rosana Jane. Médico. Conduta. Teoria da imprevisão. Caso fortuito. Força maior. Nexo causal: em matéria de responsabilidade, o exame da conduta do médico deve ser aferido com flexibilidade. Revista dos Tribunais, ano 89, vol. 781, nov. de 2000, p. 130.
} 
devido pelos adolescentes que praticarem atos infracionais, nos termos do art. 116 do Estatuto da Criança e do Adolescente, no âmbito das medidas socioeducativas ali previstas".

Com referência aos enfermos ou deficientes mentais, o art. $3^{\circ}$, II, do Código Civil entende que eles são irresponsáveis, visto que não possuem o total discernimento para a prática de atos na vida civil, devendo responder por eles os curadores (art. 932, II do Código Civil).

O Código Civil em seu art. 928, a seu turno, dispõe que o incapaz deverá responder subsidiariamente no caso de seus responsáveis não tiverem a obrigação ou meios suficientes.

\title{
1.1.1.2 Culpa latu sensu e Culpa stricto sensu
}

Na culpa stricto sensu, a conduta é lícita e torna-se ilícita na medida em que se afasta do que se espera de um homo medius, do homem ideal, vindo a atingir o resultado em razão da inobservância do dever de cautela ou de cuidado. Nesse contexto, só podemos cogitar a culpa quando o evento for previsível, caso contrário, estaremos diante de excludentes de responsabilidade como caso fortuito e força maior.

A culpa stricto sensu ou aquiliana decorre da imprudência, negligência ou imperícia. A imprudência é uma conduta positiva indevida ou precipitada, em que não há ausência de habilidade, ou seja, o médico, não é imperito, e, além disso, sabe do possível risco de tal comportamento, mas, mesmo assim, decide agir. Assim, a imprudência se caracteriza pela falta de cuidado, pelo descaso do médico. Nesse sentido, o Tribunal de Justiça do Estado do Rio de Janeiro entendeu que:

\begin{abstract}
AMPUTAÇÃO DE ANTEBRAÇO DE MENOR IMPÚBERE. DESCASO DO PROFISSIONAL DA SAÚDE. DEMONSTRADA A RESPONSABILIDADE SUBJETIVA POR ERRO MÉDICO. DANO MORAL, MATERIAL E ESTÉTICO COMPROVADOS. EXISTENNCIA DE PROVAS QUE COMPROVAM A CONDUTA CULPOSA DO MÉDICO. Por não ser a medicina uma ciência exata, o compromisso assumido pelo médico configura-se em uma obrigação de meio, não de resultado. No entanto, no caso em tela, resta evidente que a imprudência do réu rendeu ensejo à realização de uma intervenção cirúrgica traumática através da amputação do antebraço. Assim, presentes os elementos configuradores da responsabilidade civil subjetiva do réu, especificamente a culpa do médico e o nexo de causalidade, há que se manter o dever de indenizar $(\ldots)^{4}$.
\end{abstract}

\footnotetext{
${ }^{4}$ Tribunal de Justiça do Estado do Rio de Janeiro. Apelação no 2008.001.20234, Des. Fernando do Nascimento, Décima Nona Câmara Cível, Julgado em 05/08/2008.
} 
A imperícia é a falta de técnica para exercer determinada profissão ou função, levando-se em conta a capacidade médica mediana e ausência de observância das regras da sua profissão. Assim, existem médicos que sem a habilidade específica, se aventuram a realizar cirurgias plásticas e, em decorrência da inabilidade, provocam o dano.

Neste caso, o STJ entendeu que:

Responsabilidade civil. Cirurgia para redução de mamas. Paciente obesa. Súmula no 07 da Corte. Embargos de declaração. Súmula nº 98 da Corte.

1. Examinada a prova dos autos pelo Acórdão recorrido, com a indicação de que faltou o médico com o dever de informação sobre os riscos da cirurgia, ainda mais tratando-se de paciente obesa, com sua ausência durante o pós-operatório que teve complicações, aliada à falta de prova de ter a autora exercido atividade que teria causado o problema e, ainda, inexistente prova da especialização do médico para a execução do tipo de cirurgia realizada, presente está a Súmula $\mathrm{n}^{\circ} 07$ da Corte, não havendo as alegadas violações aos artigos 131 e 458 do Código de Processo Civil.

2. Nos termos da Súmula $n^{\circ} 98$ da Corte não são protelatórios os embargos de declaração para fins de prequestionamento.

3. Recurso especial conhecido e provido, em parte $^{5}$.

Quando nos referimos a erro de diagnóstico, que será abordado no próximo capítulo, não estamos diante da imperícia, "dadas as circunstâncias que envolvem a análise dos sintomas, às vezes confusos. Ocorreria aí o chamado "erro honesto"”, de acordo com Veloso de França ${ }^{6}$.

Aníbal Bruno salienta que:

Na medicina, por exemplo, em certas circunstâncias, é sempre possível um erro de diagnóstico que pode acarretar consequiências mais ou menos graves. Há erro escusável, e não imperícia, sempre que o profissional, empregando correta e oportunamente os conhecimentos e regras da sua ciência, chega a uma conclusão falsa, possa, embora, advir daí um resultado de dano ou de perigo ${ }^{7}$.

Por fim, a negligência, nada mais é do que uma conduta omissa, em que o agente, no momento da ação, não utiliza as precauções necessárias para evitar o dano, de acordo com as exigências da própria medicina, como, por exemplo, o esquecimento de um objeto dentro

\footnotetext{
5 Superior Tribunal de Justiça. Resp 332025/MG. Ministro Carlos Alberto Menezes Direito, Terceira Turma, Julgado em 28/05/2002.

${ }^{6}$ FRANÇA, Genival Veloso de., Comentários ao Código de Ética Médica, 2. ed., Rio de Janeiro: Guanabara Koogan, 1997, p. 26 apud KFOURI NETO, Miguel. Responsabilidade do Médico. 6. ed. rev., atual e ampl. São Paulo: Revista dos Tribunais, 2007, p. 94.

${ }^{7}$ BRUNO, Aníbal. Direito penal, parte geral, v. I, t. 2, p. 472 apud MAGRINI, Rosana Jane. Médico. Conduta. Teoria da imprevisão. Caso fortuito. Força maior. Nexo causal: em matéria de responsabilidade, o exame da conduta do médico deve ser aferido com flexibilidade. Revista dos Tribunais, ano 89, vol. 781, nov. de 2000 ., p. 130.
} 
do corpo do paciente, erro grave de diagnóstico ou, ainda, falta de higiene. Desta forma, o Tribunal de Justiça do Estado do Rio Grande do Sul entendeu que:

RESPONSABILIDADE CIVIL. ERRO MÉDICO. NEGLIGÊNCIA NA CONDUÇÃO DO ATENDIMENTO. OMISSÃO NA REALIZAÇÃO DE EXAMES MAIS ACURADOS. MORTE DO PACIENTE POR HEMORRAGIA INTERNA E TAMPONAMENTO CARDÍACO. NEXO CAUSAL CARACTERIZADO. DEVER DE INDENIZAR RECONHECIDO. DANOS MORAIS. QUANTUM. MANUTENÇÃO. PENSIONAMENTO REDIMENSIONADO. 1. RESPONSABILIDADE CIVIL. Hipótese em que o profissional requerido efetivamente não empregou a diligência que se lhe impunha no tratamento do paciente, não tendo procedido a uma análise mais acurada do estado clínico da vítima, de sorte a constatar a hemorragia interna a tempo de contêla, evitando a morte. Agiu, é verdade, com inescondível desídia, de sorte a retirar da vítima uma oportunidade concreta do salvamento de sua vida. Por conseguinte, o réu, com sua conduta omissiva, contribuiu para a morte da vítima, impingindo sofrimento moral aos demandantes, daí restando configurados, além de sua culpa, o dano e o nexo de causalidade cujo reconhecimento reclama o dever de indenizar, à luz do disposto no $\S 4^{\circ}$ do art. 14 do Código de Defesa do Consumidor ${ }^{8}$.

Assim, Sérgio Cavalieri Filho, ao dispor sobre a negligência, imprudência e imperícia, estabelece que:

\begin{abstract}
A falta de cautela exterioriza-se através da imprudência, da negligência e da imperícia. Não são, como se vê, espécies de culpa, nem elementos desta, mas formas de exteriorização da conduta culposa. A imprudência é falta de cautela ou cuidado por conduta comissiva, positiva, por ação. (...) Negligência é a mesma falta de cuidado por conduta omissiva. (...) O médico que não toma os cuidados devidos ao fazer uma cirurgia, ensejando a infecção do paciente, ou que lhe esquece uma pinça no abdômen, é negligente. A imperícia, por sua vez, decorre de falta de habilidade no exercício de atividade técnica, caso em que se exige, de regra, maior cuidado ou cautela, do agente ${ }^{9}$.
\end{abstract}

Como observado, não se pode confundir a negligência com a imperícia, isso porque, "se, por exemplo, um médico injeta no paciente soro antitetânico sem o necessário teste, será negligente; mas, se assim se comporta porque não sabe que se deve proceder à referida prova, demonstrará imperícia"10.

Portanto, se não for comprovado que o profissional de medicina agiu com negligência, imprudência ou imperícia, deve-se entender que o insucesso da intervenção cirúrgica se deu em razão de um infortúnio imprevisível ou de características próprias do

\footnotetext{
${ }^{8}$ Tribunal de Justiça do Estado do Rio Grande do Sul, Apelação Cível No 70021136924, Relator: Paulo Antônio Kretzmann, Décima Câmara Cível, Julgado em 18/12/2008

${ }^{9}$ CAVALIERI FILHO, Sérgio. Programa de Responsabilidade Civil. 7. ed. São Paulo: Atlas, 2007, p. 36.

${ }^{10}$ KFOURI NETO, Miguel. Responsabilidade do Médico. 6. ed. rev., atual e ampl. São Paulo: Revista dos Tribunais, 2007, p, 92.
} 
paciente, não podendo obrigar o médico a reparar o dano ocorrido. É o que afirma o julgado do Tribunal de Justiça do Rio de Janeiro:

\begin{abstract}
Responsabilidade civil médica. Cirurgia plástica. Dano material e moral. Inexistência de erro médico. Laudo pericial e depoimento do médico que reoperou a apelante que afirmam a inexistência de conduta imprudente, imperita ou negligente do cirurgião. Comprovado que o médico procedeu dentro da melhor técnica, antes prestando as informações acerca do resultado da cirurgia e dando o devido acompanhamento pós-operatório, inexiste qualquer obrigação de indenizar. Desprovimento do recurso ${ }^{11}$.
\end{abstract}

Já na culpa lato sensu, verificamos que o agente viola intencionalmente o dever jurídico, a fim de alcançar o resultado desastroso, ou seja, o dolo. Assim, a conduta nasce ilícita, visto que desde o início, o agente visa atingir um resultado antijurídico. Podemos dizer que a culpa latu sensu envolve não só a culpa stricto sensu, como também o dolo.

\title{
1.1.2 Relação de Causalidade
}

A relação de causalidade é de suma importância para o direito civil, na medida em que estabelece uma relação entre a conduta humana e a modificação do mundo exterior, ou seja, o dano. Assim, Sérgio Cavalieri Filho afirma que o nexo causal nada mais é do que o "vínculo, a ligação ou relação de causa e efeito entre a conduta e o resultado. (...) é um elemento referencial entre a conduta e o resultado. É através dele que poderemos concluir quem foi o causador do dano". ${ }^{12}$ Neste sentido, cabe a vítima demonstrar o prejuízo, a conduta culpável e o liame de causalidade, caso contrário, não incide o direito a uma reparação.

Para que seja excluído esse nexo causal em decorrência de caso fortuito, faz-se necessário que este esteja diretamente relacionado com o dano, caso contrário o agente será responsabilizado, mas nada impede que essa responsabilidade seja atenuada, cabendo ao juiz o exame concreto.

\footnotetext{
11 Tribunal de Justiça do Rio de Janeiro. Apelação nº 2004.001.14125. Desembargador Sérgio Lucio Cruz. Décima Quinta Câmara Cível, Julgado em 30/06/2004.

${ }^{12}$ CAVALIERI, Sérgio Filho. Programa de Responsabilidade Civil. 7. ed. São Paulo: Atlas, 2007, p. 46.
} 
A busca pela verdadeira causa do dano, em algumas situações, se depara com obstáculos, na medida em que surgem as concausas, vários fatores que concorrem para a produção do resultado.

As concausas preexistentes são aquelas que já existiam no momento da conduta, como por exemplo, condições de saúde da própria vítima, no caso de agravamento do resultado em razão de acidente, por ser a vítima cardíaca. Essas concausas, por si só, não eliminam a relação de causalidade entre a conduta e o dano, e, por esta razão, não diminuem a responsabilidade do agente, segundo Sérgio Cavalieri ${ }^{13}$. No mesmo caso, a concausa superveniente e a concomitante também não favorecem o agente, na medida em que elas por si só não produzem o resultado.

Além disso, essas concausas podem ser sucessivas ou simultâneas. Nas concausas simultâneas, verificamos que mais de uma causa pode provocar um dano, como por exemplo, no caso de várias pessoas, em razão de seus atos, produzirem o prejuízo a um terceiro. Neste caso, elas devem responder solidariamente, como induz o art. 942 do Código Civil.

Art. 942. Os bens do responsável pela ofensa ou violação do direito de outrem ficam sujeitos à reparação do dano causado; e, se a ofensa tiver mais de um autor, todos responderão solidariamente pela reparação.

Parágrafo único. São solidariamente responsáveis com os autores os co-autores e as pessoas designadas no art. 932.

Já nas concausas sucessivas, encontramos uma cadeia causal entre a conduta do agente e o resultado, o que dificulta saber qual delas é a responsável pelo dano provocado. Para responder essa indagação, verificamos a existência de 3 (três) teorias: da equivalência das condições, da causalidade adequada e a dos danos diretos e imediatos.

\subsubsection{Teorias da relação de causalidade}

A primeira teoria, da equivalência das condições, pode ser denominada também de condição sine qua non, porquanto, dever ser considerada como causa, qualquer circunstância que concorreu para a produção do dano, ou seja, do resultado lesivo. Essa teoria recebe muitas

\footnotetext{
${ }^{13}$ CAVALIERI, Sérgio Filho, Programa de Responsabilidade Civil. 7. ed. São Paulo: Atlas, 2007, p. 59.
} 
críticas, de acordo com Carlos Roberto Gonçalves ${ }^{14}$, em razão de sua inflexibilidade, até porque, neste caso, na hipótese de um homicídio, por exemplo, o próprio fabricante da arma utilizada deveria ser responsabilizado.

A teoria da causalidade adequada considera como causa, a condição que por si só, é apta para produzir o resultado. Assim, deve-se levar em consideração a possibilidade e a probabilidade de uma determinada causa determinar o dano, ou seja, quanto maior a probabilidade, mais adequada é a causa, a fim de ensejar a responsabilidade ao agente.

Por fim, a teoria da causa próxima ou dos danos diretos e imediatos é um meiotermo das teorias anteriores. Assim, o agente só seria responsabilizado pelos danos causados proximamente da sua conduta e, por esta razão, a causa mais próxima exclui as demais, devendo considerar como causa próxima não só a causa imediata, mas sim aquela que foi decisiva para a ocorrência do dano, como afirma Carlos Roberto Gonçalves ${ }^{15}$.

O Código Civil, para solucionar as dificuldades enfrentadas com o surgimento das concausas, adotou a teoria do dano direto e imediato, como pode ser observado no art. 403:

Art. 403. Ainda que a inexecução resulte de dolo do devedor, as perdas e danos só incluem os prejuízos efetivos e os lucros cessantes por efeito dela direto e imediato, sem prejuízo do disposto na lei processual.

\subsubsection{Dano}

Para que o agente seja responsável civilmente, faz-se necessário que sua conduta tenha provocado um dano, ou seja, uma diminuição do patrimônio de outrem ou uma lesão a um bem, em razão da inobservância de uma norma jurídica, ou seja, por mais que a conduta seja ilícita, o agente não será responsabilizado, caso o dano não ocorra, tendo em vista um dos pressupostos da Responsabilidade Civil.

\footnotetext{
${ }^{14}$ GONÇALVES, Carlos Roberto. Direito Civil Brasileiro. vol. IV. São Paulo: Saraiva, 2007, p. 330-331.

${ }^{15}$ GONÇALVES, Carlos Roberto. Op. cit., p. 331-333.
} 
Neste sentido, Mário Júlio de Almeida Costa afirma que: "na perspectiva da responsabilidade civil, cabe dizer-se, liminarmente, que dano ou prejuízo é toda a ofensa de bens ou interesses alheios protegidos pela ordem jurídica"16.

Nos casos de o dano ser atual e certo, surge a obrigação de indenizar, segundo Carlos Roberto Gonçalves ${ }^{17}$. O dano atual é aquele que já existe "no momento da ação de responsabilidade", e o certo é o "fundado sobre um fato preciso e não sobre uma hipótese". Assim, "um dano futuro não justifica uma ação de indenização", a não ser que ele seja uma conseqüência do dano atual, de acordo com Carlos Roberto Gonçalves, seguindo os ensinamentos de Henri Lalou ${ }^{18}$.

Essa obrigatoriedade de reparação plena de todos os danos causados a vítima, de forma independente e acumulável, está relacionado, principalmente, com o princípio da dignidade humana. Como dispõe a Constituição Federal:

Art. $5^{\circ}$ Todos são iguais perante a lei, sem distinção de qualquer natureza, garantindo-se aos brasileiros e aos estrangeiros residentes no País a inviolabilidade do direito à vida, à liberdade, à igualdade, à segurança e à propriedade, nos termos seguintes:

V - é assegurado o direito de resposta, proporcional ao agravo, além da indenização por dano material, moral ou à imagem;

$\mathrm{X}$ - são invioláveis a intimidade, a vida privada, a honra e a imagem das pessoas, assegurado o direito a indenização pelo dano material ou moral decorrente de sua violação;

Assim, a pessoa ofendida deve ser reparada de forma que seja restaurada a situação anterior e caso isso não seja possível, ela faz jus a uma recompensa monetária. No entanto, cabe a vítima, em regra, a prova do dano, como salienta José de Aguiar Dias:

O que o prejudicado deve provar, na ação, é o dano, sem consideração ao seu 'quantum', que é matéria da liquidação. Não basta, todavia, que o autor mostre que o fato de que se queixa, na ação, seja capaz de produzir dano, seja de natureza prejudicial. É preciso que prove o dano concreto, assim entendida a realidade do dano que experimentou, relegando para a liquidação a avaliação do seu montante. ${ }^{19}$

\footnotetext{
${ }^{16}$ COSTA, Mário Júlio de Almeida. Direito das Obrigações. 6. ed. Coimbra: Almedina, 1994, p. 496.

${ }^{17}$ GONÇALVES, Carlos Roberto. Direito Civil Brasileiro, vol. IV. São Paulo: Saraiva, 2007, p. 338.

${ }^{18}$ LALOU, Henri. Traité pratique de La responsabilité civile, n. 137 apud GONÇALVES, Carlos Roberto. Op. cit., p, 338.

${ }^{19}$ DIAS, José de Aguiar. Da responsabilidade civil. 11. ed., Rio de Janeiro: Renovar, 2006, p. 102.
} 
Por sorte, há casos em ocorre uma inversão do ônus da prova, ou seja, a culpa, neste caso, é presumida, como por exemplo, o que dispõe o art. 936 do Código Civil, em que o dono de um animal deve responder pelo prejuízo experimentado pela vítima.

Os danos indenizáveis podem ser à pessoa e à coisa, além de patrimoniais ou materiais e extrapatrimoniais.

\subsubsection{Danos à coisa}

Nos danos à coisa patrimonial, o agente deve devolver o bem, ou em caso de impossibilidade, ressarcir a vítima pelos danos causados, ou seja, cabe ao agente compensar a vítima através de uma indenização monetária, de acordo com Carlos Roberto Gonçalves ${ }^{20}$. Já os danos à coisa extrapatrimonial, cabe ao agente uma indenização, como no caso de dano a um bem de afeição, previsto no art. 952, parágrafo único do Código Civil de 2002.

Art. 952.

Parágrafo único. Para se restituir o equivalente, quando não exista a própria coisa, estimar-se-á ela pelo seu preço ordinário e pelo de afeição, contanto que este não se avantaje àquele.

\subsubsection{Danos à pessoa}

Com relação aos danos contra a pessoa, verificamos que os danos podem ser patrimoniais ou materiais, morais e estéticos.

Os danos patrimoniais ou materiais são aqueles que afetam o patrimônio econômico da vítima, "incidindo sobre interesses de ordem financeira, apreciados monetariamente", como salienta Eneas de Oliveira Matos ${ }^{21}$. Eles decorrem, geralmente, dos danos físicos, tais como: lucros cessantes, o tratamento médico até a recuperação, e as despesas extraordinárias decorrentes do dano. Nesses casos, as verbas patrimoniais só serão

\footnotetext{
${ }^{20}$ GONÇALVES, Carlos Roberto. Direito Civil Brasileiro, vol. IV. São Paulo: Saraiva, 2007, p. 337.

${ }^{21}$ OLIVEIRA MATOS, Eneas de. Dano Moral e Dano Estético. Rio de Janeiro: Renovar, 2008, p. 59.
} 
devidas após a averiguação de prova irrefutável, e devem abranger o percentual arbitrado pelo perito, de acordo com o grau da depreciação ou inabilidade.

Enquanto isso, os danos extrapatrimonias atingem a integridade física (dano estético), moral (dano moral) e psíquica (dano psíquico). A responsabilidade civil, nestes casos, tem-se tornado tão importante, que algumas teorias "notoriamente estão assumindo posição pelo interesse público da responsabilidade civil, e não mais meramente de solução de um conflito entre particulares, sem importância ou reflexo na sociedade, ou até para o Estado",22.

Alguns autores distinguem "ressarcimento", "reparação" e "indenização”. Assim, Carlos Roberto Gonçalves entende que:

\begin{abstract}
Ressarcimento é o pagamento de todo o prejuízo material sofrido, abrangendo o dano emergente e os lucros cessantes, o principal e os acréscimos que lhe adviriam com o tempo e com o emprego da coisa. Reparação é a compensação pelo dano moral, a fim de minorar a dor sofrida pela vítima. E a indenização é reservada para a compensação do dano decorrente de ato lícito do Estado, lesivo do particular, como ocorre nas desapropriações ${ }^{23}$.
\end{abstract}

O dano à integridade física pode ser estético, que nada mais é do que uma modificação involuntária, certa e permanente na integridade física externa, causando um enfeamento, como uma cicatriz no rosto; ou um dano biológico, caracterizado por uma ofensa à integridade física interna, como a perda de um rim. No entanto, no momento da indenização, o dano biológico segue a denominação de dano estético.

A reparação do dano estético será arbitrada pelo juiz levando em conta a extensão do dano, de acordo com a gravidade da lesão física determinada pela prova pericial; a localização, como, por exemplo, se for no rosto, a visualização é maior ainda; a possibilidade de reparação; e características peculiares da vítima, como o sexo e a profissão.

Essa prova pericial deverá ser realizada, indispensavelmente ${ }_{2}$ na fase processual de conhecimento, como observa o $1^{\circ}$ TAC-SP: "Prova - Perícia - Indenização por dano físico decorrente de acidente de trânsito - Realização relegada para a fase de execução da sentença -

\footnotetext{
22 OLIVEIRA MATOS, Eneas de. Dano Moral e Dano Estético. Rio de Janeiro: Renovar, 2008, p, 2.

${ }^{23}$ GONÇALVES, Carlos Roberto. Direito Civil Brasileiro, vol. IV. São Paulo: Saraiva, 2007, p. 339.
} 
Inadmissibilidade - Matéria que deve ser apurada na fase de conhecimento - Sentença anulada"24.

$\mathrm{O}$ valor a ser arbitrado pelo juiz tem como finalidade compensar a dor e o sofrimento causados pelo dano, e deve levar em consideração as posses do ofensor e a situação econômica do ofendido, na medida em que não pode ocorrer um enriquecimento da vítima com a perda ou a ofensa a sua integridade física e o valor não deve ser inexpressivo para o ofensor, a fim de que este não venha a cometer novas lesões.

Além disso, não precisa haver a perda na capacidade laborativa para que seja declarado o dano estético e o dano moral, em razão dos danos patrimoniais e extrapatrimonias serem independentes e cumuláveis, como induz a súmula $\mathrm{n}^{\circ} 37$ do STJ, no qual, "são cumuláveis as indenizações por dano material e dano moral oriundos do mesmo fato".

No caso de ofensa à integridade, é possível que a vítima requeira uma reparação por danos morais, em razão de um forte abalo emocional, ou seja, "terá de causar a vítima humilhações, tristezas, desgostos, constrangimentos, isto é, a pessoa deverá sentir-se diferente do que era - menos feliz" ${ }^{, 25}$. Neste caso, no entanto, nos deparamos com uma grande dificuldade, tal como quantificar o dano moral pecuniariamente a fim de se estabelecer o valor a ser indenizado.

Por sorte, a vítima direta do dano é a que deve pleitear a indenização por danos morais, mas nada impede que terceiros tenham legitimidade extraordinária para interpor essa ação. Assim, Oliveira Matos afirma, de acordo com os ensinamentos de Marcel Planiol, que trata-se de "típica hipótese de dano indireto, por ricochete, onde independentemente do dano causado à vítima direta, ocorre outro dano, tendo em vista aquele primeiro dano ocasionado, devendo todos serem indenizados, vez que todo os lesados possuem o seu direito à reparação de forma autônoma",26.

No Código Civil de 2002, não há previsão legal acerca do limite dos legitimados para requerer esse pedido de reparação, entretanto, podemos utilizar por analogia, segundo Oliveira Matos, o art. 12 do Código Civil, no qual terá legitimidade o cônjuge, ou qualquer outro parente em linha reta ou colateral até o quarto grau. Assim, continua o autor, em caso de

\footnotetext{
$241^{\circ}$ TAC - SP, RT 635/223 apud OLIVEIRA MATOS, Eneas. Dano Moral e Dano Estético. Rio de Janeiro: Renovar, 2008, p. 111.

${ }^{25}$ LOPEZ, Teresa Ancona. O dano estético: responsabilidade civil. 3. ed. rev . e atual. São Paulo: Revista dos Tribunais, 2004, p. 54.

${ }^{26}$ PLANIOL, Marcel. Traité élémentaire de droit civil. Paris: F. Pichon, 1900. t.2, p. 278 apud OLIVEIRA MATOS, Eneas. Dano Moral e Dano Estético. Rio de Janeiro: Renovar, 2008, p. 122.
} 
estrito interesse, "é cabível a legitimidade extraordinária nesse caso, e mediante presunção relativa aos parentes mais próximos do ofendido em sua integridade física, e mediante o ônus da prova para os demais terceiros, como noivos e amigos" 27 .

Nos danos extrapatrimonias (morais e estéticos), por mais que a maior parte da doutrina entenda pela impossibilidade de acumulação, a jurisprudência do STJ admite a reparação autônoma dos danos morais e estéticos, porquanto tratam de bens jurídicos tutelados diferentemente, na medida em que no primeiro caso, o bem jurídico tutelado é a integridade moral, já nos danos estéticos podemos dizer que é a integridade física, segundo Eneas de Oliveira Matos ${ }^{28}$.

As normas de reparação também são distintas; por mais que para o referido autor, essa normalização não se faz necessário, na medida em que:

Entender que os direitos da personalidade necessitam de positivação para a proteção é o mesmo que negar sua existência, haja vista toda a teoria construída no sentido de que se tratam de direitos inatos, inerentes, à pessoa humana: não é necessário ter norma para se ter direito ao nome, à honra, à integridade física ${ }^{29}$.

No entanto, continua Eneas, "todos sabemos que a orientação dominante pela não reparação do dano moral antes da $\mathrm{CF} / 88$ se deveu à falta de norma expressa a conceder tal reparação" ${ }^{\text {30 }}$. Assim, com relação aos danos morais, podemos citar o art. $5^{\circ}$, incs. V e X, da Constituição Federal, como já foi abordado, e com relação ao dano estético observamos os arts. $6^{\circ}$ e 196, da Constituição Federal, que induz que:

Art. $6^{\circ}$ São direitos sociais a educação, a saúde, o trabalho, a moradia, o lazer, a segurança, a previdência social, a proteção à maternidade e à infância, a assistência aos desamparados, na forma desta Constituição.

Art. 196. A saúde é direito de todos e dever do Estado, garantido mediante políticas sociais e econômicas que visem à redução do risco de doença e de outros agravos e ao acesso universal e igualitário às ações e serviços para sua promoção, proteção e recuperação.

\footnotetext{
${ }^{27}$ OLIVEIRA MATOS, Eneas. Eneas. Dano Moral e Dano Estético. Rio de Janeiro: Renovar, 2008, p.124-125.

${ }^{28}$ OLIVEIRA MATOS, Eneas. Op. cit., p. 27.

${ }^{29}$ OLIVEIRA MATOS, Eneas. Op. cit., p. 38-39.

${ }^{30}$ OLIVEIRA MATOS, Eneas. Op. cit., p. 39.
} 
Além disso, verificamos que o dano estético é de cunho objetivo, porquanto o valor arbitrado pelo juiz está relacionado com a gravidade da lesão. Já o dano moral é de cunho subjetivo, na medida em que para a reparação, faz-se necessária uma análise casuística da ofensa causada à integridade moral.

\subsection{Excludentes da Responsabilidade Civil}

Verificamos que nem sempre o agente deve ser responsabilizado pelo dano causado à vítima, em razão do rompimento do nexo causal por uma das excludentes de responsabilidade, como: culpa exclusiva da vítima; caso fortuito e força maior; fato de terceiro; estado de necessidade; legítima defesa, exercício regular do direito e estrito cumprimento do dever legal.

\subsubsection{Culpa Exclusiva da Vítima}

Neste caso, há um rompimento do liame de causalidade do ato e do prejuízo causado, em decorrência do próprio comportamento do ofendido. Assim, o médico não deverá ser responsabilizado, por exemplo, quando o resultado danoso é fruto do descumprimento das prescrições médicas pelo paciente ou, ainda, quando há omissão das informações relevantes, como os sintomas.

No entanto, caso a vítima e o ofensor contribuam para a produção do dano, as responsabilidades serão dividas, de acordo com a participação de cada um, é o que denominamos de culpa concorrente da vítima, disposto no art. 945 do Código Civil:

Art. 945. Se a vítima tiver concorrido culposamente para o evento danoso, a sua indenização será fixada tendo-se em conta a gravidade de sua culpa em confronto com a do autor do dano. 


\subsubsection{Caso Fortuito e Força Maior}

O Código Civil em seu art. 393, § único dispõe que:

Art. 393. O devedor não responde pelos prejuízos resultantes de caso fortuito ou força maior, se expressamente não se houver por eles responsabilizado.

Parágrafo único. O caso fortuito ou de força maior verifica-se no fato necessário, cujos efeitos não era possível evitar ou impedir.

O caso fortuito decorre de um ato alheio à vontade das partes, é imprevisível e inevitável, como a guerra e a greve; enquanto a força maior é fruto de um acontecimento natural e, além disso, é inevitável por mais que seja previsível, como um terremoto ou um raio. Nesses casos, o agente não deve ser responsabilizado civilmente, em decorrência da inevitabilidade e ausência de culpa, ocasionado pelo rompimento do nexo causal entre a ação ou omissão do agente e o prejuízo causado à vítima.

Existem alguns requisitos para que seja configurado o caso fortuito e força maior, tais como: não pode haver culpa do agente, o fato deve ser inevitável e superveniente e, por fim, o fato tem que ser irresistível. Neste contexto, Rui Stoco salienta que: "um fato poderá, ou não, ser classificado como de força maior e isentará, ou não, de responsabilidade, conforme se possa caracterizar, ou não, por força do critério misto, quer dizer, pelo pressuposto da inevitabilidade e da ausência de culpa do agente." 31

Agostinho Alvim ${ }^{32}$ distingue o caso fortuito externo e o fortuito interno, sendo que apenas aquele, ligado à natureza, exclui a responsabilidade, na medida em que o fortuito interno, relacionado à pessoa e à coisa são previsíveis, como por exemplo, o estouro de um pneu de ônibus.

Assim, o médico não deverá responder pelos danos provocados à vítima, se estes decorrerem de caso fortuito ou força maior, ou seja, se o insucesso do tratamento se deu em razão de circunstâncias imprevisíveis e inesperadas, como pode ser observado em algumas decisões jurisprudenciais.

${ }^{31}$ STOCO, Rui. Responsabilidade civil e sua interpretação jurisprudencial: doutrina e jurisprudência. 4. ed., São Paulo: Revista dos Tribunais, 1999, p. 86.

${ }^{32}$ ALVIM, Agostinho. Da inexecução das obrigações e suas conseqüências. 3. ed. São Paulo: Jurídica e Universitária, 1966. 


\title{
1.2.3 Fato de Terceiro
}

Há casos em que o evento danoso decorre de um ato de terceiro, e, por esta razão, rompe-se o nexo causal entre a conduta do agente e o prejuízo causado à vítima. Caio Mário traz algumas considerações acerca da relação agente-vítima.

\begin{abstract}
Esta se decompõe, nos dois pólos ativo e passivo: as pessoas do agente e da vítima. Considera-se, então, terceiro qualquer outra pessoa, estranha a este binômio, que influi na responsabilidade pelo dano. Mas para que seja excludente, é mister que por sua conduta atraia os efeitos do fato prejudicial e, em consequiência, não responda o agente, direta ou indiretamente, pelos efeitos do dano. ${ }^{33}$
\end{abstract}

A culpa de terceiro não exonera o agente da obrigação de indenizar a vítima, mas caberá ação de regresso, de acordo com o art. 930 do Código Civil. Além disso, poderá a vítima propor a ação diretamente contra o terceiro, mas caberá a ela, o ônus da prova de culpa deste terceiro.

Assim, nos casos em que o fato de terceiro é imprevisível e inevitável, como no caso fortuito ou força maior, o agente causador direto do dano não deve ser responsabilizado pelos prejuízos causados, de acordo com Carlos Roberto Gonçalves ${ }^{34}$, e a ação de indenização deverá ser proposta contra o terceiro.

\subsubsection{Estado de Necessidade}

O Estado de Necessidade está disposto no art. 188, II, § único, do Código Civil, em que:

Art. 188. Não constituem atos ilícitos:

II - a deterioração ou destruição da coisa alheia, ou a lesão a pessoa, a fim de remover perigo iminente.

Parágrafo único. No caso do inciso II, o ato será legítimo somente quando as circunstâncias o tornarem absolutamente necessário, não excedendo os limites do indispensável para a remoção do perigo.

\footnotetext{
${ }^{33}$ PEREIRA, Caio Mário da Silva. Responsabilidade Civil. 3. ed., Rio de Janeiro: Forense, 1992, p. 298.

${ }^{34}$ GONÇALVES, Carlos Roberto. Direito Civil Brasileiro, vol. IV. São Paulo: Saraiva, 2007, p. 440.
} 
A pessoa que age em estado de necessidade destrói ou deteriora bem alheio em razão perigo iminente. No entanto, para que seja caracterizada essa excludente é preciso que o comportamento seja necessário e que não se exceda o limite imposto para que seja afastado esse perigo.

Esse ato praticado em estado de necessidade, de acordo com a lei, não deve ser considerado como um ato ilícito, mas nada exclui a reparação do prejuízo, até porque como afirma José de Aguiar Dias, "não há argumento capaz de convencer-nos de que o direito que temos de lesar a outrem em estado de necessidade seja mais forte e mais merecedor de proteção do que o que assiste ao prejudicado de se ver reposto na situação anterior ao dano." ${ }^{35}$

Assim, o art. 929 do Código Civil, induz que a pessoa lesada ou o dono da coisa terão direito a indenização se não forem culpados pelo evento.

Art. 929. Se a pessoa lesada, ou o dono da coisa, no caso do inciso II do art. 188, não forem culpados do perigo, assistir-lhes-á direito à indenização do prejuízo que sofreram.

Entretanto, caso a culpa seja de um terceiro, o ofensor poderá impetrar uma ação regressiva contra o verdadeiro responsável pelo dano, como afirma o art. 930 do Código Civil:

Art. 930. No caso do inciso II do art. 188, se o perigo ocorrer por culpa de terceiro, contra este terá o autor do dano ação regressiva para haver a importância que tiver ressarcido ao lesado.

\subsubsection{Legítima Defesa, Exercício Regular do Direito e Estrito Cumprimento do Dever Legal}

O art. 188, I, do Código Civil, dispõe que:

Art. 188. Não constituem atos ilícitos:

I - os praticados em legítima defesa ou no exercício regular de um direito reconhecido.

\footnotetext{
${ }^{35}$ DIAS, José de Aguiar. Da responsabilidade civil. 11. ed., Rio de janeiro: Renovar, 2006, p. 675.
} 
Como já afirmado, quem comete o dano, mesmo em estado de necessidade, deve reparar a vítima, o que não ocorre no caso de legítima defesa, exercício regular do direito e estrito cumprimento do dever legal.

$\mathrm{O}$ agente não deve responder civilmente pelo dano provocado se tiver agido em legítima defesa, isso porque caso não reaja contra uma agressão injusta, atual ou iminente, poderá sofrer um dano injusto. Por esta razão, sua conduta é licita, mas se o ato praticado for excessivo, torna-se contrário ao direito, o que nada impede que o agente alegue que esse excesso se deu em decorrência de negligência ou imprudência, como está disposto no art. 186 do Código Civil.

No entanto, caso o agente venha a atingir um terceiro, subsiste o dever de indenização dos danos, mas nada impede uma ação de regresso contra o ofensor.

Neste sentido, verificamos que:

\begin{abstract}
O agente que, estando em situação de legítima defesa, causa ofensa a terceiro, por erro na execução, responde pela indenização do dano, se provocada no juízo cível a sua culpa. A possibilidade de responsabilização, no caso da legitima defesa com aberratio ictus, ou no estado de necessidade contra terceiro que não provocou o perigo, não exclui o exame da culpa do agente na causação da lesão em terceiro ${ }^{36}$.
\end{abstract}

Assim também, a legítima defesa putativa, no qual ocorre um erro de fato sobre a existência de uma agressão, ou seja, uma negligência na observação dos fatos, não exime o ofensor do dever de indenizar, conforme verificado em uma decisão do Tribunal de Justiça de São Paulo:

\begin{abstract}
Responsabilidade civil. Disparo de arma de fogo feito por quem imaginava estar sendo assaltado. Alegação de legítima defesa putativa. Absolvição sumária na esfera criminal. Hipótese que não afasta o dever de indenizar. Excludente de responsabilidade que só se aplica em sendo a legítima defesa real. ${ }^{37}$
\end{abstract}

Além disso, quem age dentro do exercício regular de seu direito e cumpre seus deveres de acordo com a lei não deve ser obrigado a reparar o dano advindo de sua conduta. Nos casos de estrito cumprimento do dever legal, o agente será isento de responsabilidade, mas nada impede que o Estado venha a ressarcir a vítima, como está disposto no art. $37, \S 6^{\circ}$,

\footnotetext{
${ }^{36}$ RSTJ, 113/290 apud GONÇALVES, Carlos Roberto. Direito Civil Brasileiro, vol. IV. São Paulo: Saraiva, 2007, p. 435.

${ }^{37}$ RT 808/224 apud GONÇALVES, Carlos Roberto. Direito Civil Brasileiro, vol. IV. São Paulo: Saraiva, 2007, p. $435-436$.
} 
da Constituição Federal. Entretanto, neste caso, o Estado não terá direito a regresso, em razão de o agente estar amparo pela excludente.

Art. 37. A administração pública direta e indireta de qualquer dos Poderes da União, dos Estados, do Distrito Federal e dos Municípios obedecerá aos princípios de legalidade, impessoalidade, moralidade, publicidade e eficiência e, também, ao seguinte:

$\S 6^{\circ}$ - As pessoas jurídicas de direito público e as de direito privado prestadoras de serviços públicos responderão pelos danos que seus agentes, nessa qualidade, causarem a terceiros, assegurado o direito de regresso contra o responsável nos casos de dolo ou culpa.

Em caso de exercício regular de direito, o agente age regularmente, de acordo com a boa fé, o fim econômico e social, e, por esta razão, não deve ser responsabilizado. No entanto, esse exercício não pode exceder ao estabelecido em lei, caso contrário, sua conduta será ilícita e haverá um abuso de direito, de acordo com o art. 187 do Código Civil.

1.2.6 Cláusula de irresponsabilidade ou de não indenizar

Esta cláusula nada mais é do que um acordo de vontades, em que se afasta a obrigação de indenizar no caso de inexecução ou erro. Assim, em favor do médico, os riscos são transferidos para a paciente que sofreu o dano, de acordo com Aguiar Dias ${ }^{38}$.

$\mathrm{Na}$ esfera penal, essa cláusula não contém nenhuma eficácia, na medida em que o Estado tem o direito de aplicar uma pena cominada na norma penal incriminadora a quem praticou uma ação ou omissão e causou um prejuízo a outrem, é o que denominamos de jus puniendi. No mesmo sentido, na esfera civil, verificamos que tanto a nossa legislação como a jurisprudência não concordam com essa cláusula. Assim, o Código Civil preceitua em seu art. 734 que:

Art. 734. O transportador responde pelos danos causados às pessoas transportadas e suas bagagens, salvo motivo de força maior, sendo nula qualquer cláusula excludente da responsabilidade.

\footnotetext{
${ }^{38}$ DIAS, José de Aguiar . Cláusula de não indenizar. 2. ed. Rio de Janeiro, 1955, p. 95 apud GONÇALVES, Carlos Roberto. Direito Civil Brasileiro. vol. IV. São Paulo: Saraiva, 2007, p. 449.
} 
O Código de Defesa do Consumidor não admite a invocação dessa cláusula de não indenizar, como pode ser observado no art. 24 , em que é "vedada a exoneração contratual do fornecedor". Além disso, o art. 25 afirma que "é vedada a estipulação contratual de cláusula que impossibilite, exonere ou atenue a obrigação de indenizar prevista nesta e nas seções anteriores". Por fim, dispõe, ainda, no art. 51, I, que a as cláusulas que "impossibilitem, exonerem ou atenuem a responsabilidade do fornecedor por vícios de qualquer natureza dos produtos e serviços ou impliquem renúncia ou disposição de direitos" serão declaradas nulas.

Isso ocorre, porque segundo Aguiar Dias, o médico já possui uma cláusula de irresponsabilidade em razão de situações peculiares da medicina, ou seja, "na proporção da margem de erro tolerada pela imperfeição da própria ciência. Portanto, onde se poderia convencioná-la, ela já existe - e fora daí, se verifica absoluta impossibilidade, pelo respeito devido ao ser humano". 39

Neste contexto, podemos dizer que não se deve ser fixada uma cláusula de irresponsabilidade ou de não indenizar, quando estamos diante de um direito alienável, como o direito à vida, que é garantido pela nossa Constituição Federal de $1988 \mathrm{em}$ seu art. 5º X, e deve ser respeitado por todos a fim de que possamos viver em uma sociedade harmônica.

\subsection{Modalidades de Responsabilidade Civil}

\subsubsection{Responsabilidade Penal, Civil e Disciplinar}

A conduta médica pode ocasionar uma responsabilidade civil, penal, e/ou disciplinar, e para isso é preciso que haja um resultado danoso, ou seja, um prejuízo para o paciente; uma ação ou omissão em desacordo com as regras preestabelecidas e, por fim, um nexo causal entre o dano propriamente dito e a conduta. Assim, por exemplo, um médico que age com imprudência ou imperícia, causando a morte ao seu paciente, deve responder pelo crime de homicídio culposo e reparar a família da vítima através de uma indenização.

No entanto, verificamos algumas distinções entre a culpa civil e penal. Neste contexto, para que o médico seja responsável penalmente, faz-se necessário que sua conduta

\footnotetext{
${ }^{39}$ DIAS, José de Aguiar . Cláusula de não indenizar, 4. ed., Rio de janeiro: forense, 1980, p. 237 apud KFOURI NETO, Miguel. Responsabilidade do Médico. 6. ed. rev., atual e ampl. São Paulo: Revista dos Tribunais, 2007, p. 100.
} 
infrinja uma norma penal de Direito Público e, consequentemente, a cominação de uma pena pelo Estado tem como finalidade a reparação do dano e o reequilíbrio da paz social. Já na responsabilidade civil, surge o direito a reparação ou indenização, em razão da violação de uma obrigação contratual e o prejuízo causado à vitima.

Além disso, Sérgio Cavalieri Filho ${ }^{40}$ afirma que os ilícitos mais graves são sancionados na lei penal, cabendo a esfera civil os crimes de menor gravidade, ou seja, que não atinja diretamente o ente público. E, por fim, na culpa penal, a responsabilidade é pessoal, não podendo passar da pessoa do condenado, enquanto na responsabilidade civil, a obrigação pode se estender as outras pessoas, como já foram visto no caso dos pais, tutores ou curadores.

$\mathrm{Na}$ responsabilidade disciplinar, verificamos o descumprimento de deveres atinentes à própria atividade profissional, regulamentado por estatutos e códigos. Portanto, cabe ao médico agir de acordo como o Código de Processo Ético-Profissional, Código de Ética Médica, Resolução CFM nº 1.246/88, DE 08.01.88, Código de Ética do Estudante de Medicina, Código Internacional de Ética dos Profissionais de Medicina do Trabalho.

No entanto, caso o médico desrespeite alguma dessas normas reguladoras, estará sujeito a algumas penalidades administrativas o que independe de reparação civil ou penal. No processo disciplinar, primeiramente, se instaura uma sindicância e, em seguida, passa-se para a fase de instrução e julgamento.

\subsubsection{Responsabilidade Contratual e Extracontratual}

A relação existente entre a vítima e o ofensor pode ser fruto de uma relação jurídica obrigacional, como o contrato, ou oriundo da própria lei. Assim, no caso na responsabilidade contratual, há um vínculo obrigacional e o agente terá que indenizar caso não venha a atingir o resultado determinado. No entanto, o dever de reparar um prejuízo causado por um agente que não possui nenhuma relação jurídica com a vítima, dá-se o nome de responsabilidade extracontratual.

\footnotetext{
${ }^{40}$ CAVALIERI FILHO, Sérgio. Programa de Responsabilidade Civil. 7. ed. São Paulo: Atlas, 2007, p. 14.
} 
Assim, Rui Stoco afirma que:

Na culpa contratual há um dever positivo de adimplir o que é objeto da avença. $\mathrm{Na}$ culpa aquiliana, é necessário invocar o dever negativo ou obrigação de não prejudicar, e, comprovado o comportamento antijurídico, evidenciar que ele repercutiu na órbita jurídica do paciente, causando-lhe um dano específico ${ }^{41}$.

O Código de Defesa do Consumidor quando se refere à responsabilidade do fornecedor de produtos e serviços, não distingue a responsabilidade contratual e extracontratual. Assim, o agente deverá indenizar, independentemente de contrato, visto que o art. 17, do referido Código, equiparam as vítimas em caso de acidente de consumo.

\subsubsection{Responsabilidade Objetiva e Subjetiva}

A teoria subjetiva pressupõe a prova da culpa, enquanto que a responsabilidade objetiva ou de risco prescinde da averiguação de culpa, bastando o dano e o nexo de causalidade para que haja o dever de indenizar. Nesse caso, a culpa pode ser presumida ou prescindível.

Na culpa presumida, há uma inversão do ônus da prova, bastando que a vítima comprove a conduta e o dano. Assim, para que o agente se exima desse dever de reparação, é necessário que demonstre alguma das excludentes de responsabilidade, como visto no item anterior. Essa responsabilidade seria a forma mais completa para proteger o paciente lesado, na medida em que não é necessária a prova de culpa.

Já na culpa prescindível, basta um nexo causal entre a conduta do agente e o prejuízo causado, como, por exemplo, o parágrafo único do art. 927, que segundo Carlos

Roberto Gonçalves ${ }^{42}$, fará com que aumente, substancialmente, o número de pedidos de indenização em razão de dano. Este parágrafo dispõe que:

${ }^{41}$ STOCO, Rui. Responsabilidade civil e sua interpretação jurisprudencial: doutrina e jurisprudência. 4. ed., São Paulo: Revista dos Tribunais, 1999, p. 68.

${ }^{42}$ GONÇALVES, Carlos Roberto. Direito Civil Brasileiro. vol. IV. São Paulo: Saraiva, 2007, p. 30-34. 
Art. 927

Parágrafo único. Haverá obrigação de reparar o dano, independentemente de culpa, nos casos especificados em lei, ou quando a atividade normalmente desenvolvida pelo autor do dano implicar, por sua natureza, risco para os direitos de outrem.

O Código Civil de 2002 adota, como regra, a teoria da responsabilidade subjetiva, como pode ser observado no art. 186, no qual faz-se necessário que o agente haja com negligência ou imprudência para que seja responsável civilmente. No entanto, há certos casos da responsabilidade civil que a própria culpa não consegue abarcar. Assim, Caio Mário afirma que:

(...) a regra geral, que deve presidir à responsabilidade civil, é a fundamentação na idéia de culpa; mas, sendo insuficiente esta para atender às imposições do progresso, cumpre ao legislador fixar especialmente os casos em que deverá ocorrer a obrigação de reparar, independentemente daquela noção. Não será sempre que a reparação do dano se abstrairá do conceito de culpa, porém quando o autorizar a ordem jurídica positiva.(....). Insurgir-se contra a idéia tradicional da culpa é criar uma dogmática desafinada de todos os sistemas jurídicos. Ficar somente com ela é entravar o processo ${ }^{43}$.

No entanto, existem alguns casos, como pode ser observado no art. 933 do Código Civil, que adotam a teoria da responsabilidade objetiva, tais como: os pais com relação aos filhos que estão sob sua autoridade ou companhia, os tutores e curadores quando tratar de seus pupilos e curatelados, os empregadores em razão de atos dos seus empregados ou prepostos, os donos de hotéis e escolas, quando os atos decorrem de hóspedes e educandos.

${ }^{43}$ SILVA PEREIRA. Caio Mário. Instituições de Direito Civil. 3. ed. Rio de Janeiro: Forense, 1992, p.507. 


\section{CAPÍTULO 2 - RESPONSABILIDADE CIVIL DO MÉDICO}

\subsection{A Evolução da Responsabilidade}

A primeira fase é a da vingança privada, na qual a vítima ou os parentes reagiam a um dano sem proporção à ofensa e sem cogitar a culpa do ofensor. Assim, essa vingança era uma "forma primitiva, selvagem, talvez, mas humana, da reação espontânea e natural contra o mal sofrido; solução comum a todos os povos nas suas origens, para a reparação do mal pelo mal". 44

Em seguida, com a evolução da sociedade, a reação da vítima teve que ser proporcional ao tamanho da ofensa. Surge, nesse momento, a pena de talião, "sangue por sangue, olho por olho, dente por dente", adotado pela Lei das XII Tábuas, em Roma; no Êxodo, pelos hebraicos e no Código de Hamurabi, na Babilônia.

Assim, o próprio Código de Hamurabi (2394 a.C.) já cominava penas àqueles que provocassem algum dano, como a lesão ou a própria morte, independentemente de culpa, como pode ser observado no art. 218 que afirma que: "Se um médico fizer uma larga incisão com uma faca de operações e matar o paciente, ou abrir um tumor com uma faca de operações e cortar o olho, suas mãos deverão ser cortadas".

Após esse período, dá-se a fase da composição, em que não se cogita, ainda, a culpa e o ofensor, para se ver livre de sua condenação, deveria comprar a sua liberdade, ou seja, ao invés da retaliação, a reparação do dano se dava através do pagamento de certa quantia em dinheiro. No entanto, com o surgimento de uma autoridade soberana, a composição passou a ser obrigatória e foi proibido fazer justiça com as próprias mãos.

Dessa forma, o dever de indenização surgiu quando o Estado tomou para si o direito de punir e a finalidade principal era intimidar os agentes com penas demasiadamente severas e cruéis.

No antigo Egito, os médicos não eram punidos por mais que ocasionasse um dano ao paciente, isso porque eram tidos como sacerdotes. De outro lado, na Grécia Antiga, verifica-se um relato de Plutarco, no qual o médico foi crucificado em razão de negligência. A

\footnotetext{
${ }^{44}$ LIMA, Alvino. Da culpa ao risco. São Paulo, 1938, p. 10 apud GONÇALVES, Carlos Roberto. Direito Civil Brasileiro, vol. IV. São Paulo: Saraiva, 2007, p. 6
} 
partir da Lei de Aquília, em Roma, começa-se a falar em responsabilidade civil do médico, cabendo a este a pena pecuniária, e não mais a represália, como afirma Rosana Jane Magrini. $^{45}$

No início do século XIX, os profissionais de medicina só seriam responsabilizados no caso de danos ocorridos em razão de falta grave, imperícia e imprudência, cabendo ao paciente provar o prejuízo. No entanto, havia uma relação de confiança entre o paciente e o médico, sendo que este era tido como amigo e conselheiro. Assim, dificilmente se cogitaria um litígio entre eles.

No entanto, com o passar dos anos, a relação médico-paciente se tornou superficial. Não existe mais a figura do médico de família, amigo, e as consultas estão restritas apenas ao diagnóstico do problema. Verificamos que esse distanciamento entre o paciente e o médico contribuiu para o aumento do número de pessoas que requerem indenização em razão dos prejuízos causados por erro médico.

\subsection{A atividade profissional e a Responsabilidade Civil}

Hoje em dia, para que um determinado profissional exerça sua atividade, em alguns casos, faz-se necessário que ele preencha certos requisitos, tais como: a formação em um curso superior, residência ou especialização para atuar em determinadas áreas, e credenciamento em um órgão especial como o CRM (Conselho Regional de Medicina), no caso dos médicos.

Tudo isso não os exime de responder pelos danos causados a terceiros, até porque, com o crescimento do número de escolas de medicina, houve uma significante diminuição da qualidade técnica, e, consequentemente, um aumento dos riscos na atividade desempenhada por estes profissionais, de acordo com Alexandre Gir Gomes. ${ }^{46}$

A legislação brasileira, sobretudo, tende cada vez mais a proteger o lesado, o que, para alguns médicos, significa um entrave ao processo científico, visto que o medo de sofrer

\footnotetext{
${ }^{45}$ MAGRINI, Rosana Jane. Médico. Conduta. Teoria da imprevisão. Caso fortuito. Força maior. Nexo causal: em matéria de responsabilidade, o exame da conduta do médico deve ser aferido com flexibilidade. Revista dos Tribunais, ano 89, vol. 781, nov. de 2000, p. 122-123.

${ }^{45}$ CAVALIERI FILHO, Sérgio. Programa de Responsabilidade Civil. 7. ed. São Paulo: Atlas, 2007, p.360.

${ }^{46}$ GIR GOMES, Alexandre. Responsabilidade civil do médico nas cirurgias plásticas estética. Revista de direito Privado, ano 3, out.-dez. de 2002, p. 81.
} 
alguma punição faz com que eles prefiram uma medicina simples e rotineira, segundo Miguel Kfouri Neto ${ }^{47}$.

A Responsabilidade, neste sentido, pode ser subjetiva que é aquela fulcrada na culpa, em que o profissional de medicina não visa atingir determinado prejuízo, mas age sem diligência, resultando em um dano a terceiro; e objetiva, na qual a culpa é presumida ou dispensada e há uma violação consciente do dever jurídico. Assim, no segundo caso, para que haja a obrigação de indenizar, basta o nexo causal entre a conduta e o dano, e o médico só poderá se eximir desse dever, se conseguir provar que tal dano ocorreu em virtude de uma das excludentes de ilicitude, tais como: culpa exclusiva da vítima, força maior ou caso fortuito.

No entanto, no Brasil, para que seja caracterizada a responsabilidade médica, fazse necessária uma análise da culpa do médico, ou seja, é preciso que o agente tenha agido com negligência, imprudência ou imperícia no exercício da sua profissão, como induz Miguel Kfouri $\mathrm{Neto}^{48}$ e que haja um nexo causal entre a conduta médica e o resultado danoso.

Portanto, a responsabilidade é subjetiva, no qual o médico deverá reparar o dano, independentemente da gravidade. Neste caso, cabe ao paciente provar a falta de diligência, o que diferencia da responsabilidade objetiva, em que basta a vítima demonstrar o prejuízo, para que haja o dever de indenizar do médico.

Além disso, para o exame dessa conduta culposa é preciso que se verifique o aspecto técnico do profissional de medicina e, sobretudo, não se deixe levar pela repercussão da mídia, devendo se ater às provas constantes nos autos, como salienta Rosana Jane Magrini. $^{49}$

\subsection{Natureza Contratual da Responsabilidade Médica}

Há uma divergência entre os doutrinadores sobre a qual seria a natureza jurídica da relação entre o médico e o paciente. A responsabilidade dos profissionais de medicina é de

\footnotetext{
${ }^{47}$ KFOURI NETO, Miguel. Responsabilidade do Médico. 6. ed. rev., atual e ampl. São Paulo: Revista dos Tribunais, 2007, p.27.

${ }^{48}$ KKOURI NETO, Miguel. Op. cit., p.61-63.

${ }^{49}$ MAGRINI, Rosana Jane. Médico. Conduta. Teoria da imprevisão. Caso fortuito. Força maior. Nexo causal: em matéria de responsabilidade, o exame da conduta do médico deve ser aferido com flexibilidade. Revista dos Tribunais, ano 89, vol. 781, novembro de 2000, p. 120-121.
} 
natureza contratual ${ }^{50}$, mas alguns entendem que nada mais é do que um contrato de prestação de serviços, e outros vêem como um contrato sui generis.

Portanto, para Sérgio Cavalieri Filho, estamos diante de um contrato sui generis, visto que "o médico não se limita a prestar serviços estritamente técnicos, acabando por se colocar numa posição de conselheiro, de guarda e protetor do enfermo e de seus familiares,..." 51 , e, neste mesmo sentido, José de Aguiar Dias salienta que "tudo isso mostra que o contrato exige do médico uma consciência profissional, para cuja observação não basta a simples correção do locador de serviços" ${ }^{52}$, como o dever de informação a que o médico está submetido.

Por sorte, não resta mais dúvidas de que estamos diante de um contrato, o que não induz a presunção de culpa, como afirma o ilustre autor Aguiar Dias ${ }^{53}$, na medida em que o médico não tem a obrigação de curar ou salvar o paciente, mas de agir com prudência, utilizar as técnicas, e não infringir as regras de sua profissão. Neste sentido, a sua responsabilidade é de meio, não se podendo falar em inadimplemento contratual, caso não seja alcançado o resultado desejado pelo paciente, por mais que o médico tenha agido com toda a cautela necessária para o ato.

Assim, o objeto do contrato médico não é a cura, mas a atitude cuidadosa e atenciosa do profissional de medicina, como afirma o Dr. Jurandir Sebastião ${ }^{54}$. A paciente, neste caso, procura receber o melhor atendimento de acordo com a evolução da própria medicina, caso contrário, o médico estará prestando um serviço de qualidade inferior, o que poderá ocasionar um prejuízo maior ainda para aquele que busca os seus serviços.

\subsection{A Responsabilidade do médico e a legislação pátria}

Após a entrada em vigor do Código de Defesa do Consumidor, em 11 de setembro de 1990, os serviços prestados por médicos, hospitais e clínicas começaram a ser subordinados a esse instituto e, por esta razão, o art. $6^{\circ}$, enumerou alguns direitos do

\footnotetext{
${ }^{50}$ A não ser nos casos de atendimento de emergência ou em instituições de saúde pública, que não ocorre um acordo prévio entre as partes e, por esta razão, trata-se de uma responsabilidade extracontratual.

${ }^{51}$ CAVAliERI FILHO, Sérgio. Programa de Responsabilidade Civil. 7. ed. São Paulo: Atlas, 2007, p.360.

${ }^{52}$ DIAS, José de Aguiar. Da responsabilidade civil. Rio de janeiro: Renovar, 11. ed, 2006, p. 330.

${ }^{53}$ DIAS, José de Aguiar. Op. cit., p. 330-331.

${ }^{54}$ Jurandir Sebastião, COAD, Seleções Jurídicas. A responsabilidade civil, a singularidade da medicina e a aplicação do direito, p. 52 apud DIAS, José de Aguiar. Op. cit., p. 333
} 
consumidor/paciente, tais como: direito à vida, saúde e segurança (art. $6^{\circ}$, I), direito à informação adequada e clara (art. $\left.6^{\circ}, \mathrm{III}\right)$, proteção contra propagandas enganosas $\left(\operatorname{art.} 6^{\circ}, \mathrm{IV}\right)$, efetiva prevenção e reparação de danos (art. $6^{\circ}$, IV) e facilitação de defesa (art. $6^{\circ}$, VIII).

No entanto, devemos examinar a Responsabilidade Civil sob dois ângulos: a prestação de serviços exercida por um profissional liberal e a exercida de forma empresarial, como é o caso de hospitais, laboratórios médicos, clínicas, casas de saúde, dentre outros, isso porque o Código de Defesa do Consumidor consagra a responsabilidade objetiva, como pode ser observado no art. 14:

Art. 14. O fornecedor de serviços responde, independentemente da existência de culpa, pela reparação dos danos causados aos consumidores por defeitos relativos à prestação dos serviços, bem como por informações insuficientes ou inadequadas sobre sua fruição e riscos.

Desta mesma forma, os médicos que trabalham em hospitais, seja públicos ou privados, serão responsabilizados objetivamente, ou seja, o hospital responderá independentemente de averiguação de culpa, cabendo uma ação regressiva contra os médicos. Assim, o Código Civil no art. 932, III, entende que o empregador é responsável pela reparação civil no caso de danos cometidos pelos seus empregados e, o art. 933 dispõe que essa responsabilidade do empregador é objetiva.

Art. 932. São também responsáveis pela reparação civil:

III - o empregador ou comitente, por seus empregados, serviçais e prepostos, no exercício do trabalho que lhes competir, ou em razão dele;

“Art. 933. As pessoas indicadas nos incisos I a V do artigo antecedente, ainda que não haja culpa de sua parte, responderão pelos atos praticados pelos terceiros ali referidos.

No entanto, o $\S 4^{\circ}$ do Código de Defesa do Consumidor pressupõe a averiguação de culpa quando se tratar de profissionais liberais, não podendo falar em responsabilidade civil quando for demonstrado que o médico agiu com prudência, por mais que o resultado do tratamento não tenha sido positivo, visto que a obrigação do médico é de meio e não de resultado.

Os profissionais liberais só poderão ser responsabilizados quando for provada a existência de alguma das modalidades da culpa, tais como: negligência, imprudência ou 
imperícia, isso porque, segundo Ada Pellegrini Grinover e outros, "os médicos e advogados para citarmos alguns dos mais conhecidos profissionais - são contratados ou constituídos com base na confiança que inspiram aos respectivos clientes" 55 .

Assim, quando nos referimos aos profissionais liberais, devemos fazer menção ao Código Civil de 2002 que no art. 951 dispõe que:

Art. $951 \mathrm{O}$ disposto nos arts. 948, 949 e 950 aplica-se ainda no caso de indenização devida por aquele que, no exercício de atividade profissional, por negligência, imprudência ou imperícia, causar a morte do paciente, agravar-lhe o mal, causar-lhe lesão, ou inabilitá-lo para o trabalho.

Desta forma, a responsabilidade do médico como profissional liberal é subjetiva e em casos de erro médico, caberá ao paciente, ou seus herdeiros, demonstrar a culpa do agente. Para tal, nada impede que o juiz inverta o ônus da prova em favor da vítima, em razão da complexidade técnica a que este instituto está submetido, conforme o art. $6^{\circ}$, III Código de Defesa do Consumidor:

Art. $6^{\circ}$ São direitos básicos do consumidor:

VIII - a facilitação da defesa de seus direitos, inclusive com a inversão do ônus da prova, a seu favor, no processo civil, quando, a critério do juiz, for verossímil a alegação ou quando for ele hipossuficiente, segundo as regras ordinárias de experiências.

Com relação a esse artigo, verificamos que o termo hipossufiente não se destina apenas àqueles que não detêm uma condição econômica suficiente para custear a produção de prova, como também pode abranger a falta de técnica do paciente ou até mesmo de conhecimento, na medida em que, muitas vezes, o paciente encontra-se sedado durante a intervenção cirúrgica e, consequentemente, não sabe como se procedeu a intervenção médica que ocasionou o prejuízo.

A partir da inversão do ônus da prova, há a presunção relativa de culpa do profissional de medicina, ou seja, para que o médico se exima da responsabilidade, cabe a ele

55 GRINOVER, Ada Pellegrini... [et al.]. Código de Defesa do Consumidor comentado pelos autores do anteprojeto, 8. ed. Rio de Janeiro: Forense Universitária, 2004, p. 196. 
a prova de que o resultado esperado não ocorreu em decorrência de circunstâncias imprevisíveis e não em razão de imprudência, negligência ou imperícia.

Para Ênio Santarelli Zuliani ${ }^{56}$ o momento oportuno para que se proceda a inversão do ônus da prova é no início da fase probatória, para que o médico, sabendo dessa inversão, possa produzir a prova esperada a fim de se eximir, se for o caso, da obrigação de reparar o paciente.

Alguns doutrinadores, como Tupinambá Nascimento ${ }^{57}$, entendem que por ter sido estabelecida a responsabilidade subjetiva dos profissionais de medicina, de acordo com o art. 14, $\S 4^{\circ}$, do Código de Defesa do Consumir, não seria possível a inversão do ônus da prova. Para Miguel Kfouri Neto ${ }^{58}$ essa inversão probatória ensejaria na aplicação da responsabilidade objetiva para os profissionais liberais que só poderiam se eximir da responsabilidade se demonstrado alguma excludente, tais como: força maior, caso fortuito e culpa exclusiva da vítima.

No entanto, Marco Aurélio Bortowski afirma que essa inversão não exclui o aspecto subjetivo, na medida em que:

A circunstância de ter o legislador adotado a responsabilidade subjetiva no concernente ao fornecimento de serviços pelo profissional liberal não impede, a nosso juízo, a inversão dos ônus da prova. A uma, porque, presentes os pressupostos do inc. VIII do art. $6^{\circ}$, a inversão da carga probatória apenas obriga o profissional liberal a demonstrar que não laborou com culpa, em quaisquer modalidades. Ora esse procedimento não retira o caráter subjetivo da responsabilidade; apenas transfere o encargo ao próprio demandado. A ele caberá a demonstração de que não houve culpa. ${ }^{59}$

A jurisprudência está dividida com relação à possibilidade ou não de inversão do ônus da prova, mas um julgado do STJ entendeu que é possível desde que a alegação seja verossímil e o consumidor seja tido como hipossuficiente:

\footnotetext{
56 ZULIANI, Ênio Santarelli. Responsabilidade Civil Fundada em erro Médico: Inversão do Ônus da Prova. Revista Síntese de Direito Civil e Processual Civil, ano V, nº 26, nov.-dez. 2003, p. 155.

${ }^{57}$ NASCIMENTO, Tupinambá. Responsabilidade civil no Código de Defesa do Consumidor. Rio de janeiro: Aide, 1991.

${ }^{58}$ KFOURI NETO. Miguel. Culpa Médica e ônus da prova. São Paulo: Revista dos Tribunais, 2002, p. 149 e 151 apud WEBER, Marcia Regina Lusa Cadore. Responsabilidade civil do médico. Revista de Direito Privado, ano 5, abril-junho de 2004, p. 161.

${ }^{59}$ BORTOWSKI, Marco Aurélio. A carga probatória segundo a doutrina e o Código de Defesa do Consumidor. Revista de direito do consumidor 7/112, São Paulo: RT, jul.-set.1993 apud WEBER, Márcia Regina Lusa Cadore. Op. cit., p. 160.
} 
RESPONSABILIDADE CIVIL. MÉDICO E HOSPITAL. INVERSÃO DO ÔNUS DA PROVA. RESPONSABILIDADE DOS PROFISSIONAIS LIBERAIS MATÉRIA DE FATO E JURISPRUDÊNCIA DO STJ (REsp. No 122.505-SP).

1. No sistema do Código de Defesa do Consumidor a "responsabilidade pessoal dos profissionais liberais será apurada mediante a verificação de culpa" (art. 14, § $4^{\circ}$ ).

2. A chamada inversão do ônus da prova, no Código de Defesa do Consumidor, está no contexto da facilitação da defesa dos direitos do consumidor, ficando subordinada ao "critério do juiz, quando for verossímil a alegação ou quando for ele hipossuficiente, segundo as regras ordinárias de experiências" (art. 6 $6^{\circ}$, VIII). Isso quer dizer que não é automática a inversão do ônus da prova. Ela depende de circunstâncias concretas que serão apuradas pelo juiz no contexto da facilitação da defesa" dos direitos do consumidor. E essas circunstâncias concretas, nesse caso, não foram consideradas presentes pelas instâncias ordinárias.

3. Recurso especial não conhecido. ${ }^{60}$

Como demonstrado, a responsabilidade subjetiva só deveria atingir os profissionais liberais, até porque, como afirma Antonio Herman Vasconcellos Benjamin, essa exceção do $\S 4^{\circ}$ do art. 14, não se refere às pessoas jurídicas, e, por esta razão, “(....) se o médico trabalha para um hospital, responderá ele apenas, por culpa, enquanto a responsabilidade civil do hospital será apurada objetivamente" ${ }^{61}$.

Para o Tribunal de Justiça do Estado do Rio de Janeiro entendeu que:

Responsabilidade Civil Hospitalar. Prestação de Serviço Defeituoso. Dever de Indenizar Independentemente de Culpa. Como prestadores de serviços que são, os estabelecimentos hospitalares respondem objetivamente pela reparação dos danos causados aos consumidores. Essa responsabilidade tem por fato gerador o defeito do serviço, conforme expressamente previsto no artigo 14 do CDC, que, em última instância, criou para o fornecedor um dever de segurança e idoneidade em relação aos serviços que presta aos consumidores. Simples traumatismo no dedo de um menor que, não obstante o atendimento medico recebido, acaba se transformando em infecção grave a ponto de se fazer necessária a amputação cirúrgica da terceira falange, caracteriza falha do serviço e leva à indenização independentemente de culpa. Provimento parcial do recurso ${ }^{62}$.

Assim, para que houvesse o dever de reparação do hospital, bastaria a comprovação do dano sofrido pelo paciente, e só as excludentes do art. 14 , § $3^{\circ}$ poderiam eximir a casa hospitalar de tal obrigação, ou seja, para que o hospital não fosse responsabilizado, seria necessária a prova de que o evento não ocorreu em razão de defeito de

\footnotetext{
${ }^{60}$ Superior Tribunal de Justiça. Resp 171988/RS. Ministro Waldemar Zveiter. Terceira Turma. Julgado em 24/05/1999.

${ }^{61}$ BENJAMIN, Antonio Herman Vasconcellos. Comentários ao Código de Proteção ao Consumidor, p. 79-80 apud KFOURI NETO, Miguel. Responsabilidade do Médico. 6. ed. rev., atual e ampl. São Paulo: Revista dos Tribunais, 2007, p.199.

${ }_{62}$ Tribunal de Justiça do Estado do Rio de Janeiro. Apelação no 1998.001.11323. Desembargador Sérgio Cavalieri Filho. Segunda Câmara Cível. Julgado em 15/12/1998.
} 
serviço e sim em decorrência das próprias condições do paciente ou por motivo de força maior.

Art. 14

$\S 3^{\circ} \mathrm{O}$ fornecedor de serviços só não será responsabilizado quando provar:

I - que, tendo prestado o serviço, o defeito inexiste;

II - a culpa exclusiva do consumidor ou de terceiro.

O serviço defeituoso está previsto no Código de Defesa do Consumidor, art. 14, $\S^{\text {o: }}$ :

\begin{abstract}
Art. 14 quais:

I - o modo de seu fornecimento;

II - o resultado e os riscos que razoavelmente dele se esperam;

III - a época em que foi fornecido.
\end{abstract}

$\S 1^{\circ} \mathrm{O}$ serviço é defeituoso quando não fornece a segurança que o consumidor dele pode esperar, levando-se em consideração as circunstâncias relevantes, entre as

Nota-se que o defeito nada mais é do que uma falha do dever de segurança dos serviços e da qualidade dos produtos fornecidos, como afirma Bruno Miragem ${ }^{63}$. Assim, no caso de reparação, nada impede que o médico e a instituição hospitalar respondam solidariamente quando os dois forem responsáveis pelo defeito, como previsto no art. $7^{\circ}$, parágrafo único do CDC:

Art. 7

Parágrafo único. Tendo mais de um autor a ofensa, todos responderão solidariamente pela reparação dos danos previstos nas normas de consumo.

No entanto, com relação à responsabilidade objetiva imposta pelo art. 14 do Código de Defesa do Consumidor, encontramos decisões jurisprudenciais, que mesmo se tratando de pessoas jurídicas, essa responsabilidade não é aplicada, isso porque requerem a análise da conduta médica:

63 MIRAGEM, Bruno. Responsabilidade civil médica no Direito civil brasileiro. Revista de Direito do Consumidor. Ano 16, n. 63, jul.-set. 2007, p. 82. 
Responsabilidade civil. Hospital. Ajuizamento com base no Código de Defesa do Consumidor. Responsabilidade objetiva. Inadmissibilidade. Hipótese de exercício de profissão liberal, na medida em que o que se põe em exame é o próprio trabalho médico. Necessidade de prova de que o réu agiu com culpa ou dolo. Art. 14, $\S 3^{\circ}$, do referido Código. Recurso não provido.

Em caso de indenização contra hospital, ajuizada com base no Código de Defesa do Consumidor, embora se trate de pessoa jurídica, a ela não se aplica a responsabilidade objetiva, na medida em que se põe em exame é o próprio trabalho médico. Aplicável, pois, o $\$ 4^{\circ}$, do art. 14 do referido Código ${ }^{64}$.

E, neste mesmo sentido, Miguel Kfouri Neto ${ }^{65}$, afirma que por mais que exista um vínculo empregatício entre o médico e o hospital, é de suma importância a prova da culpa, ou seja, a verificação da conduta do médico.

Assim, como visto em uma decisão do Superior Tribunal de Justiça (STJ), a responsabilidade objetiva do art. 14 do Código de Defesa do Consumidor só será aplicada no caso de prejuízos relacionados ao estabelecimento, tais como: os equipamentos ou instalações.

CIVIL. INDENIZAÇÃO. MORTE. CULPA. MÉDICOS. AFASTAMENTO. CONDENAÇÃO. HOSPITAL. RESPONSABILIDADE. OBJETIVA. IMPOSSIBILIDADE. 1 - A responsabilidade dos hospitais, no que tange à atuação técnico-profissional dos médicos que neles atuam ou a eles sejam ligados por convênio, é subjetiva, ou seja, dependente da comprovação de culpa dos prepostos, presumindo-se a dos preponentes. Nesse sentido são as normas dos arts. 159, 1521, III, e 1545 do Código Civil de 1916 e, atualmente, as dos arts. 186 e 951 do novo Código Civil, bem com a súmula 341 - STF (É presumida a culpa do patrão ou comitente pelo ato culposo do empregado ou preposto.). 2 - Em razão disso, não se pode dar guarida à tese do acórdão de, arrimado nas provas colhidas, excluir, de modo expresso, a culpa dos médicos e, ao mesmo tempo, admitir a responsabilidade objetiva do hospital, para condená-lo a pagar indenização por morte de paciente. 3 - $O$ art. 14 do CDC, conforme melhor doutrina, não conflita com essa conclusão, dado que a responsabilidade objetiva, nele prevista para o prestador de serviços, no presente caso, o hospital, circunscreve-se apenas aos serviços única e exclusivamente relacionados com o estabelecimento empresarial propriamente dito, ou seja, aqueles que digam respeito à estadia do paciente (internação), instalações, equipamentos, serviços auxiliares (enfermagem, exames, radiologia), etc e não aos serviços técnicos-profissionais dos médicos que ali atuam, permanecendo estes na relação subjetiva de preposição (culpa) ${ }^{66}$. (grifo nosso)

\footnotetext{
${ }^{64}$ RJTJSP-Lex 141/248 apud KFOURI NETO, Miguel. Responsabilidade do Médico. 6. ed. rev., atual e ampl. São Paulo: Revista dos Tribunais, 2007, p.200.

${ }^{65}$ KFOURI NETO, Miguel. Op. cit., p.202.

${ }^{66}$ Superior Tribunal de Justiça. Resp 258389, Ministro Fernando Gonçalves, Quarta Turma, Julgado em $16 / 06 / 2005$.
} 


\section{5 Prova da Culpa}

De acordo com o art. 333, Código de Processo Civil, cabe ao autor provar o fato constitutivo do seu direito, enquanto o réu deve provar algum fato impeditivo, modificativo ou extintivo do direito do autor, a fim de se eximir da responsabilidade. Assim, como o contrato de prestação médica é uma obrigação de meio, faz-se necessário que o paciente demonstre a culpa do profissional. A prova poderá ser realizada através de testemunhas ou perícia médica, quando se tratar de assunto técnico e, ainda, deve haver um nexo causal entre a conduta e o dano causado à vítima, como salienta José de Aguiar Dias ${ }^{67}$.

No entanto, a dificuldade é muito grande, até porque os Tribunais são exigentes, só admitindo erros grosseiros no diagnóstico, na medicação ou no tratamento e, por tratar de uma matéria muito técnica, é essencial a prova pericial, o que pode ser influenciada em nome da solidariedade profissional. Assim, Luiz da Cunha Gonçalves afirma que, em muitos casos, os depoimentos das testemunhas são mais "importantes que as opiniões científicas dos peritos, às vezes empenhados em atenuar ou suprimir essa responsabilidade, por espírito de classe, que frequentemente se sobrepõe à verdade" 68 .

O juiz não é obrigado a julgar de acordo com o parecer do perito, mas este auxilia na hora de examinar a conduta do profissional de medicina. Diante desses fatos, verificamos que não cabe ao Poder Judiciário examinar questões cientificas, e sim:

(...) estabelecer quais cuidados possíveis que ao profissional cabia dispensar ao doente, de acordo com os padrões determinados pelos usos da ciência, e confrontar essa norma concreta, fixada para o caso, como comportamento efetivamente adotado pelo médico. Se ele não observou, agiu com culpa, $(. . .)^{69}$.

Neste momento, devemos fazer uma distinção entre erro profissional e culpa médica, visto que no primeiro caso, a conduta é correta, mas a técnica utilizada não é, e no caso da culpa médica, a técnica é correta, mas o profissional agiu sem diligência, ou seja, a

\footnotetext{
${ }^{67}$ DIAS, José de Aguiar. Da responsabilidade civil. Rio de janeiro: Renovar, 11. ed, 2006, p.334.

${ }^{68}$ GONÇALVES, Luiz da Cunha. Tratado de direito civil, v. XII, t. II, p. 967 apud ZULIANI, Ênio Santarelli. Responsabilidade Civil Fundada em erro Médico: Inversão do Ônus da Prova. Revista Síntese de Direito Civil e Processual Civil, ano V, no 26, nov.-dez. 2003, p. 151.

69 RT 718/38, artigo sobre a Responsabilidade civil do médico do Min. Ruy Rosado de Aguiar Jr. apud CAVALIERI FILHO, Sérgio. Programa de Responsabilidade Civil. 7. ed. São Paulo: Atlas, 2007, p. 361.
} 
conduta é incorreta, se for levado em consideração o padrão esperado. Assim, Carvalho Santos salienta que:

Os Tribunais não têm o direito de examinar, [...] se o médico afastou-se das regras de sua profissão, abordando a questão de ordem científica, de apreciação e de prática médica, não lhes sendo lícito, tampouco, decidir coisa alguma sobre a oportunidade de uma intervenção cirúrgica, sobre o método preferível a empregar, ou sobre o melhor tratamento a seguir. As questões puramente técnicas escapam à sua competência e devem se limitar a indagar-se, da parte do médico, se houve imprudência, negligência ou imperícia, notória e manifesta, consistente em erro grosseiro capaz de comprometer a reputação de qualquer profissão ${ }^{70}$.

A tramitação dos processos de apuração de responsabilidade do médico tem se prolongado excessivamente. Cabe ao juiz dar maior celeridade e colher as provas no momento em que ocorreu o dano para que elas não sejam contaminadas com circunstâncias alheias.

De acordo com Miguel Kfouri Neto ${ }^{71}$, os meios de prova são: depoimento do médico e da testemunha, prova documental e pericial, informes como as notícias da imprensa que clamam o fervor da sociedade, e por fim, o próprio convencimento do juiz.

${ }^{70}$ BASTOS, Freitas. Código Civil Brasileiro interpretado, 7. ed., v. XXI, p. 260-261apud CAVALIERI FILHO, Sérgio. Programa de Responsabilidade Civil. 7. ed. São Paulo: Atlas, 2007, p. 362.

${ }^{71}$ KFOURI NETO, Miguel. Responsabilidade do Médico. 6. ed. rev., atual e ampl. São Paulo: Revista dos Tribunais, 2007, p. 86. 


\section{6 Direitos e Deveres do paciente e do médico}

O paciente tem o dever de remunerar o médico, seguir todas as prescrições estabelecidas, e obter informações do profissional, tais como: faculdade de medicina em que se formou; especialidade; médico que poderá substituí-lo, em caso de necessidade.

O paciente tem o direito de pleitear a reparação do dano causado por falta de diligência do médico e de gravar ou filmar os atos médicos. Além disso, tem o direito de obter todas as informações sobre o seu problema e cópias das documentações como prontuários, exames, laudos, até porque tudo isso será um importante meio de prova para o futuro, caso seja necessário. Assim, dispõe o art. 5, XIV da Constituição Federal:

Art. $5^{\circ}$

XIV - é assegurado a todos o acesso à informação e resguardado o sigilo da fonte, quando necessário ao exercício profissional;

De acordo com os arts. 70, 71 e 112 do Código de Ética Médica, cabem aos médicos e hospitais esclarecer as dúvidas e fornecer os documentos médicos do paciente.

Já com relação aos deveres do médico, podemos separar em três momentos: o antes, o durante e o depois do tratamento, segundo Miguel Kfouri Neto ${ }^{72}$. Primeiramente, cabe ao médico um bom atendimento, ouvir o paciente, questioná-lo e diagnosticar o problema. Em seguida, informar o diagnóstico, prognóstico, levando em consideração o aspecto psicológico do paciente, riscos e objetivos, de acordo com o art. 59, do Código de Ética Médica, e caso necessário, solicitar ajuda de outro profissional.

É vedado ao médico:

Art. 59 - Deixar de informar ao paciente o diagnóstico, o prognóstico, os riscos e objetivos do tratamento, salvo quando a comunicação direta ao mesmo possa provocar-lhe dano, devendo, nesse caso, a comunicação ser feita ao seu responsável legal.

\footnotetext{
72 KFOURI NETO, Miguel. Responsabilidade do Médico. 6. ed. rev., atual e ampl. São Paulo: Revista dos
} Tribunais, 2007, p. 31. 
Durante o tratamento, deve se proceder de acordo com as técnicas, regras e métodos da medicina a fim de tentar alcançar a cura, e, por fim, após o tratamento, deve acompanhar o paciente, estando à disposição para eventuais irregularidades e esclarecimentos.

No entanto, José de Aguiar Dias ${ }^{73}$ afirma que o médico possui 5 (cinco) deveres: conselho, cuidado, obtenção de consentimento, abstenção de abuso ou desvio de poder e, por fim, dever de sigilo. Assim, cabe ao médico: determinar a natureza e a origem da doença; informar o tratamento adequado e as chances de cura; instruir o paciente com relação às precauções necessárias; informar os riscos atinentes a este e os efeitos colaterais que poderão advir da intervenção; atender aos chamados telefônicos; e realizar as visitas quando necessário, ou seja, o médico não pode abandonar o paciente, mas nada impede que ele seja substituído por um assistente, em caso de muito trabalho.

Além disso, deve obter o consentimento do paciente após a exposição dos riscos e benefícios do tratamento, não realizar experiências médicas a não ser que seja de suma importância para a cura da doença, exercer a atividade profissional de forma adequada, sem abuso ou desvio de poder. Por fim, é vedado ao médico revelar as informações prestadas pelo paciente ou apuradas através de exames, é o que denominamos de dever de sigilo, disposto no art. 102 do Código de Ética Médica.

No que diz respeito à responsabilização em caso de quebra de sigilo, verificamos que o médico, não deve responder quando as informações prestadas são para o órgão segurador, em que se solicita reembolso das despesas efetuadas com o tratamento, é o que dispõe a Apelação 1995.001.05910:

Seguro saúde. Responsabilidade civil. Sigilo de cadastro. Médico. Morte do paciente. Dano moral e dano material.

Ordinária de indenização. Dano moral e material. Não constitui ilícito, consistente na divulgação de doença, a informação prestada pelo hospital, ou pelo médico responsável, da doença do paciente internado à empresa responsável pelo pagamento da internação e dos honorários. Se a remoção do paciente para outro hospital se fez com as cautelas necessárias, não há que se cogitar de dano material se o mesmo vem a falecer em razão da moléstia. Ação julgada improcedente. Recurso desprovido. Sentença confirmada ${ }^{74}$.

\footnotetext{
73 DIAS, José de Aguiar. Da responsabilidade civil. 11. ed. Rio de janeiro: Renovar, 2006, p. 337.

${ }^{74}$ Tribunal de Justiça do Estado do Rio de Janeiro. Apelação Cível no 1995.001.05910, Relator Luiz Eduardo Rabello, Quarta Câmara Cível, julgado em 9/05/1996.
} 
Em sentido contrário, o Superior Tribunal de Justiça, no Recurso Especial 159.527 entende que:

SIGILO. ERRO MÉDICO. Prontuário. Clínica. Seguradora. Viola a ética médica a entrega de prontuário de paciente internado à companhia seguradora responsável pelo reembolso das despesas ${ }^{75}$.

Nota-se que essas informações, no caso acima transcrito, não podem ser entregues a terceiros, como a seguradora, a fim de que não haja nenhuma ofensa aos princípios da dignidade humana e da personalidade, como entende Cláudia Lima Marques ${ }^{76}$.

Assim, o Conselho Federal de Medicina acerca dessa discussão afirma que:

Resta-nos a reafirmar que o prontuário do paciente, contendo dados de interesse médico, não é instrumento de cobrança de serviços e sim repositório de sua via médica, pertencendo a ele, paciente, e à instituição que tem a sua posse no sentido físico e é responsável por sua guarda $(. . .)^{77}$.

Assim, o dever de sigilo deve ser respeitado, só podendo ser encaminhado para a seguradora um relatório com algumas informações que justifiquem o tratamento e o tempo necessário de internação no hospital, é o que dispõe o Conselho Federal de Medicina no Processo $429 / 93^{78}$.

\section{6. 1 Dever de informação e obtenção de consentimento}

Com relação à atividade médica, podemos dizer que existe o risco inerente, inevitável, o que não pode ser resultado de uma má prestação de serviço é o que denominados de iatrogenia. Os médicos e os hospitais, nesses casos, não respondem por esses riscos, a não ser que haja falta de informação.

Portanto, o dever de prestar a informação adequada é um dos mais importantes do profissional de medicina e, por esta razão, faz-se necessário abordá-lo separadamente dos demais deveres do médico.

\footnotetext{
${ }^{75}$ Superior Tribunal de Justiça, Recurso Especial 159.527/RJ, Relator Ministro Ruy Rosado de Aguiar, Julgado em 14/04/1998.

${ }^{76}$ MARQUES, Cláudia Lima. A responsabilidade dos médicos e do hospital por falha no dever de informar ao consumidor. Revista dos Tribunais, ano 93, volume 827, set. 2004, p. 44.

77 Conselho Federal de Medicina, Processo 4842/93, fls. 88 apud DIAS, José de Aguiar. Da responsabilidade civil. 11. ed. Rio de janeiro: Renovar, 2006, p. 348

${ }^{78}$ Conselho Federal de Medicina, Processo 429/93 apud DIAS, José de Aguiar. Op. cit., p. 348.
} 
A necessidade de informação se dá porque, o paciente sabendo de seu estado de saúde, do tratamento a ser empregado e das conseqüências que poderão advir, dá ou não o consentimento para a realização, é o que denominamos de consentimento informado, que deverá ser individualizado, voluntário, por escrito e realizado perante testemunhas, como afirma Miguel Kfouri Neto ${ }^{79}$.

Neste sentido, o Superior Tribunal de Justiça dispôs que:

Responsabilidade civil. Médici. Consentimento informado. A despreocupação do facultativo em obter do paciente seu consentimento informado pode significar nos casos mais graves - negligência no exercício profissional. As exigências do princípio do consentimento informado devem ser atendidas com maior zelo na medida em que aumenta o risco, ou o dano. Recurso conhecido ${ }^{80}$.

O dever de informar os riscos reais do tratamento está disposto no Art. $6^{\circ}$, III, do Código de Defesa do Consumidor, no qual cabe ao médico revelar "a informação adequada e clara sobre os diferentes produtos e serviços, com especificação correta de quantidade, características, composição, qualidade e preço, bem como, sobre os riscos que apresentem", por mais que eles sejam raros.

Assim, cabe ao médico informar qual o melhor tratamento a ser empregado e quais os riscos atinentes a este tratamento de forma clara, levando em consideração de que se está diante de uma pessoa leiga, é o que dispõe Fernando Noronha. Para o referido autor, esse dever de informação deve ser dividido em: "deveres de esclarecimento (sobre especialidades que não sejam do conhecimento geral das pessoas), de conselho (sobre as possibilidades e opções disponíveis) e de advertência (quanto aos riscos possíveis)" ${ }^{81}$.

Eugênio Facchini Neto afirma que:

Trata-se do dever do médico de esclarecer e informar o paciente, em modo claro e inteligível, do quadro clínico diagnosticado, apresentando-lhe as alternativas de tratamento (quer clínico, quer cirúrgico), expondo-lhe os riscos e possíveis consequências de cada uma das alternativas, com os correlativos benefícios e vantagens. Assim, informado, o paciente poderá fazer uma escolha consciente ${ }^{82}$.

\footnotetext{
${ }^{79}$ KFOURI NETO, Miguel. Responsabilidade do Médico. 6. ed. rev., atual e ampl. São Paulo: Revista dos Tribunais, 2007, p.181.

${ }^{80}$ Superior Tribunal de Justiça. Resp 436827. Min. Ruy Rosado de Aguiar. Julgado em 1/10/2002.

${ }^{81}$ NORONHA, Fernando. Âmbito da responsabilidade civil. Revista Trimestral de direito Civil 12/47, out.dez. 2002 apud MARQUES, Cláudia Lima. A responsabilidade dos médicos e do hospital por falha no dever de informar ao consumidor. Revista dos Tribunais, ano 93, volume 827, set. 2004, p. 24.

${ }^{82}$ FACCHINI NETO, Eugênio. Da responsabilidade civil no novo Código In: SARLET, Ingo (Org.). O novo Código Civil e a Constituição. Porto Alegre: Livraria do Advogado, 2003, p. 192.
} 
O ônus da prova quanto a esse direito do paciente caberá ao médico ou ao hospital, e para que seja estabelecido o dever de indenizar, faz-se necessário um nexo causal entre a falta de informação e o prejuízo. Quando houver ausência de consentimento informado, a quantificação da indenização, como na solução adotada com a teoria da chance perdida, não será integral. Ou seja, "não seria fixada pela totalidade do dano, isoladamente considerado, como no caso de a lesão ter sido provocada por falha técnica ou deficiente atuação médicocirúrgica, mas sim diante da probabilidade de o paciente, caso tivesse sido conveniente informado, não se submeter ao tratamento" 83 .

O médico, ao escolher o momento oportuno para prestar a informação, deve respeitar o princípio da boa fé, já que, minutos antes de uma intervenção cirúrgica, os pacientes "assinam qualquer documento e submetem-se a qualquer cláusula abusiva de renúncia de direitos (art. 51, I e IV, do CDC) ou condição excessivamente onerosa" ${ }^{84}$. Assim, como pode ser observado, o momento adequado é na fase pré contratual, antes mesmo que se inicie a prestação de serviços pelo médico.

No que diz respeito a esse dever do médico, podemos fazer uma analogia com o art. 15 do Código Civil de 2002, que dispõe: "Ninguém pode ser constrangido a submeter-se, com risco de vida, a tratamento médico ou a intervenção cirúrgica". Portanto, o paciente, além de não poder ser constrangido, também, não pode ser mal-informado, não sendo obrigado a realizar qualquer tratamento, com exceção em caso de situação emergencial. No entanto, esse consentimento informado não isenta o médico, caso este tenha agido com culpa no momento do tratamento.

Quando ocorrer algum fato novo, durante a intervenção, alguns entendem que o médico deve interromper o tratamento até que seja obtido o consentimento, mas a jurisprudência majoritária acredita que o médico deve prosseguir, desde que necessário, até porque, como afirma Miguel Kfouri Neto:

Interromper a cirurgia nessas circunstâncias é freqüentemente - senão sempre prejudicial ao paciente. Nunca é benéfico para o organismo submeter-se a várias anestesias gerais sucessivas; a primeira intervenção, se interrompida, faz aumentar o risco de possível evolução da lesão; os fenômenos inflamatórios cicatriciais tornam-se muito mais freqüentes e delicados nesse segundo ato cirúrgico que na intervenção inicial. Claro que o médico deve, na medida do possível, prevenir os

\footnotetext{
${ }^{83}$ GALÁN CORTÉS, Júlio César. Responsabilidad médica y consentimiento informado, p. 237 apud KFOURI NETO, Miguel. Responsabilidade do Médico. 6. ed. rev., atual e ampl. São Paulo: Revista dos Tribunais, 2007, p. $45-46$

${ }^{84}$ MARQUES, Cláudia Lima. A responsabilidade dos médicos e do hospital por falha no dever de informar ao consumidor. Revista dos Tribunais, ano 93, volume 827, set. 2004, p. 26-27.
} 
familiares; mas isso pode ser bem difícil, em muitos casos, no decorrer da cirurgia. $^{85}$

Em caso de impossibilidade de manifestação de vontade do doente, como, por exemplo, quando se tratar de um alienado ou menor, o consentimento deverá ser dado por aquele que detém a guarda. Portanto, para que seja realizada a intervenção ou dado início a um tratamento, faz-se necessário a obtenção de uma autorização de um parente maior, da linha reta, colateral até $2^{\circ}$ grau, ou cônjuge, por analogia ao art. $4^{\circ}$ da Lei n. 9.434/97.

Entretanto, poderá ser aberta uma exceção em caso de emergência, decorrente de um estado de necessidade ou de uma situação de perigo de vida, como uma parada cardíaca, como dispõe o art. 46 do Código de Ética Médica.

É vedado ao médico:

Art. 46 - Efetuar qualquer procedimento médico sem o esclarecimento e consentimento prévios do paciente ou de seu responsável legal, salvo iminente perigo de vida.

O médico deverá realizar o tratamento, independentemente de autorização dos familiares, e só será responsabilizado se a sua conduta for inadequada, ou seja, se agir sem a diligência necessária para efetuar o tratamento.

De outro lado, José de Aguiar Dias afirma que caso o tratamento não ofereça grandes riscos, o consentimento poderá ser dispensado e a prova deste se dá por presunção, até porque dificilmente será realizado um contrato médico por escrito de antemão, mas, sobretudo, esse consentimento se faz necessário quando: “a) nas operações cirúrgicas; b) na anestesia; c) na inoculação de vírus ou sérum; d) no tratamento ou na investigação por meio de eletricidade ou radiologia; e) de modo geral, em tudo quanto possa oferecer perigo real mais ou menos certo" 86 .

Esse dever de informação está relacionado com o princípio de transparência, que pode ser observado no art. 31 do Código de Defesa do Consumidor, no qual o fornecedor tem a obrigação de prestar as informações claras, corretas, precisas sobre o serviço, "bem como sobre os riscos que apresentam à saúde e segurança dos consumidores”. Assim, cabe ao

${ }^{85}$ KFOURI NETO, Miguel. Culpa Médica e ônus da prova. São Paulo: Revista dos Tribunais, 2002, p. 296 apud WEBER, Márcia Regina Lusa Cadore. Responsabilidade civil do médico. Revista de Direito Privado, ano 5, Revista dos Tribunais, abr.-jun. de 2004, p. 153.

${ }^{86}$ DIAS, José de Aguiar. Da responsabilidade civil. 11. ed. Rio de janeiro: Renovar, 2006, p. 341. 
médico informar "acerca do progresso da ciência e sobre a composição e as propriedades das drogas que administra, bem como sobre as condições particulares do paciente, realizando, o mais perfeitamente possível, a completa anamnese" 87 .

Verificamos que para a realização do tratamento, deve haver uma ligação entre a informação prestada pelo médico e o consentimento do paciente, até porque, aquela tem que ser completa e correta, é o que dispõe Márcia Regina Lusa Cadore Weber ${ }^{88}$. Portanto, caso o paciente não esteja totalmente esclarecido, o consentimento não é válido e o médico deverá responder por falha e defeito de informação, é o que dispõem os arts. 20 e 14, respectivamente, do Código de Defesa do Consumidor.

Por fim, após a verificação dos riscos, cabe ao médico informar ao paciente exaustivamente e de forma clara, se os riscos assumidos serão menores que os benefícios esperados, na medida em que, como afirma Judith Martins Costa, esse dever de informação visa "esclarecer ao paciente sobre a relação custo/benefício do tratamento escolhido, ou dos efeitos colaterais do medicamento indicado, ou ainda, na fase pré-contratual, de avisar o futuro contratante sobre os fatos que podem ter relevo na formação da declaração negocial" 89 .

No entanto, caso o médico, mesmo sabendo do real desequilíbrio entre o binômio risco/beneficio, execute o tratamento cirúrgico estético, deverá responder pelo seu ato, por mais que haja um consentimento prévio do paciente, na medida em que cabe ao médico agir conforme as técnicas da medicina e responder caso infrinja alguma dessas regras. Assim, verificamos que o "consentimento pode ser desconsiderado - máxime quando a possibilidade de desgraça for maior que o embelezamento esperado" 90 .

Esse dever de informação, portanto, é de suma importância, principalmente, quando nos referimos a tratamentos ou intervenções cirúrgicas desnecessárias, pelo menos, sob o prisma emergencial, como a cirurgia plástica estética. O Tribunal de Justiça do Rio Grande do Sul entendeu que:

RESPONSABILIDADE CIVIL DO MÉDICO. CIRURGIA ESTÉTICA. DEVER DE INFORMAÇÃO. PROCESSUAL CIVIL. ARBITRAMENTO DE HONORÁRIOS EM AÇÃO CAUTELAR. Constitui dever básico do cirurgião plástico a ampla informação da paciente sobre os riscos da cirurgia, especialmente os mais prováveis, como a formação de quelóides ou cicatrizes inestésicas. Cabe ao esculápio fazer a prova de que se desincumbiu do mesmo. Sem a mesma, incide a

\footnotetext{
${ }^{87}$ GONÇALVES, Carlos Roberto. Direito Civil Brasileiro, vol. IV. São Paulo: Saraiva, 2007, p. 241.

${ }^{88}$ WEBER, Márcia Regina Lusa Cadore. Responsabilidade civil do médico. Revista de Direito Privado, ano 5, Revista dos Tribunais, abr.-jun. de 2004, p. 153.

${ }^{89}$ MARTINS COSTA, Judith. A boa-fé no Direito Privado. São Paulo: Revista dos Tribunais, 1999, p. 439.

${ }^{90}$ KFOURI NETO, Miguel. Responsabilidade do Médico. 6. ed. rev., atual e ampl. São Paulo: Revista dos Tribunais, 2007, p. 181.
} 
responsabilização. (...) Dano moral e estético abrangentes, in re ipsa. Possibilidade de cumulação da indenização pelo prejuízo extrapatrimonial com a condenação a pagar consultas, tratamento e cirurgia reparadoras (...). ${ }^{91}$

\subsection{Perda de uma chance}

A ausência de informação clara e adequada e de consentimento, por exemplo, pode ocasionar a perda de uma chance, isso porque, se o paciente tivesse sido informado corretamente, poderia ter optado pela não realização do tratamento que resultou em um prejuízo. Assim, o médico que causa um dano ao paciente deve reparar-lo de forma integral, só se eximindo dessa obrigação se comprovar alguma excludente. Aquele que for privado da oportunidade de obter uma vantagem devida ou de evitar um prejuízo, também deve ser indenizado. É o que denominamos de perda de uma chance ou de uma oportunidade.

Consoante este entendimento, o acórdão do Tribunal de Justiça do Rio Grande do Sul entendeu que:

RESPONSABILIDADE CIVIL. MÉDICO. Comporta-se contra a prudência médico que dá alta a paciente, a instâncias deste, apesar de seu estado febril não recomendar a liberação, e comunicado, posteriormente, do agravamento do quadro, prescreve sem vê-lo pessoalmente. O retardamento dos cuidados, se não provocou a doença fatal, tirou o paciente razoável chance de sobreviver $(. . .)^{92}$.

Esta teoria francesa nada mais é do que a perda de uma chance de vida ou de cura real e não hipotética, em razão de um dano médico. Assim, no caso de erro de diagnóstico, o retardamento do tratamento pode ocasionar a diminuição da chance de cura de um determinado paciente, mas isso não quer dizer que se a doença fosse detectada a tempo hábil, o paciente seria preservado. Portanto, dispõe o Tribunal de Justiça do Estado do Rio Grande do Sul:

RESPONSABILIDADE CIVIL. AÇÃO DE INDENIZAÇÃO. PERDA DA CHANCE. DIAGNÓSTICO MÉDICO. Indenização por perda da chance ao tratamento médico adequado. Possibilidade. Diagnóstico de tumor adiado em razão

\footnotetext{
${ }^{91}$ Tribunal de Justiça do Rio Grande do Sul, Apelação Cível n ${ }^{\circ}$ 70004518759, Relatora: Rejane Maria Dias de Castro Bins , Nona Câmara Cível, Julgado em 11/04/2003.

${ }_{92}$ Tribunal de Justiça do Estado do Rio Grande do Sul, Apelação Cível no 592020846, Relator: Araken de Assis, Primeira Câmara Cível, Julgado em 16/02/1993.
} 
de negligência médica. Redução da possibilidade de cura. Comprovação. Danos morais. Configuração. Danos materiais. Descabimento. Apelação provida ${ }^{93}$.

Como pode ser observado, cabe a indenização, se for comprovado o nexo causal entre a conduta do médico e a perda da chance e, esse valor deve ser proporcional à possibilidade de obtenção de um determinado resultado, ou seja, quanto maior for a probabilidade, maior deverá ser o valor fixado a titulo de indenização.

Quando nos referimos à natureza jurídica, alguns autores entendem que se está diante de um lucro cessante e outros entendem que se trata de um dano emergente. Esse nada mais é do que uma efetiva e imediata diminuição do patrimônio do paciente lesado e, aquele pode ser caracterizado como tudo aquilo que a vítima deixou de lucrar.

No entanto, como a teoria da perda de uma chance está baseada na probabilidade de obtenção de um resultado, não poderíamos dizer que se está diante de um dano emergente ou de lucros cessantes.

\subsection{Erro médico}

Algumas condutas do médico acarretam a responsabilidade civil de acordo com José de Aguiar Dias ${ }^{94}$, tais como: a exposição dos pacientes a riscos e sofrimentos desnecessários, modificação do tratamento sem justificativa, a ausência de cuidados com a higiene e assepsia dos instrumentos, o receituário de medicamentos com letra ilegível, o esquecimento de um corpo estranho dentro do organismo do paciente, dentre outros.

O erro profissional não deve ser considerado, a princípio, como culpável porque decorre da dificuldade de certeza da arte médica e, muito menos, como caso de imperícia, negligencia ou imprudência. Aguiar Dias entende que este erro "é apreciado com prudente reserva pelos Tribunais. Com efeito, o julgador não deve nem pode entrar em apreciações de ordem técnica quanto aos métodos científicos que, por sua natureza, sejam passíveis de

\footnotetext{
93 Tribunal de Justiça do Estado do Rio Grande do Sul, Apelação Cível no 70018528760, Relator: Pedro Luiz Rodrigues Bossle, Quinta Câmara Cível, Julgado em 28/03/2007

${ }^{94}$ DIAS, José de Aguiar. Da responsabilidade civil. 11. ed. Rio de janeiro: Renovar, 2006, p. 350-351.
} 
dúvidas e discussões" 95 . No entanto, nada impede que ocorra a presunção de culpa, como salienta o autor Bruno Miragem ${ }^{96}$.

A iatrogenia não acarreta a responsabilidade civil do médico, visto que mesmo sendo previsível, ela é inevitável. Assim, verificamos que por mais que o médico aja com prudência e perícia, nada impede o surgimento de uma lesão iatrogênica, até porque, esta é vista, em alguns casos, como um dano necessário, para que não ocorra um prejuízo maior, como por exemplo, um corte no tecido para a retirada de um apêndice inflamado. Para tal, o médico não deve ser obrigado a indenizar em nome da excludente: exercício regular do direito, de acordo com Rui Stoco ${ }^{97}$.

Portanto, o Tribunal de Justiça do Rio Grande do Sul entendeu que:

\begin{abstract}
Responsabilidade civil. Doença de leggperthes. Dano médico. Iatrogenia. Se, por um lado, a lesão previsível - iatrogenia - é resultante do atuar medico, por outro, a imprudência, a negligência e a imperícia são causas que, uma vez comprovadas, geram a reparação civil. Definida como lesão previsível ou sequela do tratamento decorrente da invasão do corpo, a iatrogenia, ou dano iatrogênico, é também identificada como dano necessário e esperado do atuar médico. A medicina moderna, ao conceituar a iatrogenia como todo dano causado ao paciente pela ação médica ou os males provocados pelo tratamento prescrito, estanca de forma direta o ingresso no campo da responsabilidade civil, já que os profissionais médicos, que cuidam da saúde alheia, assumem uma obrigação de meio com a finalidade de aplicar a arte, pericia e zelo que detém e que seus pacientes presumem, cuja aferição de eventual desvio não vai além da reparação terapêutica. Afastado, pois, o erro médico, conclui-se que o dano suportado pelo autor é iatrogenico, previsível e necessário no tratamento a que foi submetido o autor, decorrente, pois, do atuar medico, isento de responsabilidade civil. Improvimento do recurso ${ }^{98}$.
\end{abstract}

Além disso, a iatrogenia pode decorrer de fatores do próprio paciente e, por esta razão, o médico não será responsabilizado, desde que tenha esclarecido para o paciente o tratamento a ser utilizado e quais as conseqüências possíveis para o caso em questão. A iatrogenia decorrente da omissão de informação do paciente também exclui a responsabilidade do médico quando este fator gera o insucesso do tratamento, como ser a pessoa diabética, cardíaca ou alérgica a certos medicamentos.

\footnotetext{
${ }^{95}$ DIAS, José de Aguiar. Da responsabilidade civil. 11. ed. Rio de janeiro: Renovar, 2006, p. 353.

96 MIRAGEM, Bruno. Responsabilidade civil médica no Direito civil brasileiro. Revista de Direito do Consumidor. Ano 16, n. 63, jul.-set. 2007, p. 78.

${ }^{97}$ STOCO, Rui. Iatrogenia e Responsabilidade civil do médico. Revista dos Tribunais. Ano 90, vol. 784, fev. de 2001, p. 108.

98 Tribunal de Justiça do Estado do Rio de Janeiro. Apelação n ${ }^{\circ}$ 2004.001.11913. Relator: Maldonado de Carvalho. Nona Câmara Cível. Julgado em 26/04/2005
} 
No entanto, quando a iatrogenia decorrer de atuação culposa do médico, caberá a este a obrigação de indenizar, como no caso de imprudência, em que o agente age apressadamente sem tomar os cuidados necessários, ou ainda, quando se omite em decorrência de desatenção, resultando em negligência e, por fỉm, quando há ausência de domínio técnico esperado para efetuar o tratamento, como salienta Rui Stoco ${ }^{99}$.

O erro de diagnóstico, em que se determina a doença do paciente e as causas, é escusável se não tiver ocasionado danos, porquanto, para Cunha Rodrigues, "o erro de diagnóstico não é, necessariamente, culposo, porque a ciência do médico é incerta e conjectural. Existem doenças distintas com síndromes similares. Assim, não é estranho que um médico se equivoque,..." ${ }^{100}$. No entanto, o médico deverá responder no caso de erro grosseiro e manifesto, o que demonstra ausência de cautela no momento de diagnosticar.

Neste contexto, deve ser observado se o médico agiu corretamente, certificando de todos os sintomas da doença e utilizando os recursos disponíveis, tais como: exame de laboratório, ultra-som, ressonância magnética, tomografia, dentre outros, para diagnosticar precisamente a doença do paciente e qual seria o tratamento mais adequado a fim de se obter a cura.

Por fim, verificamos que o hospital deverá responder solidariamente com relação aos atos praticados, dentro da casa hospitalar, pelo médico e que ensejam um dano, como o erro de diagnóstico grosseiro e a ausência de informação, tudo isso devido ao reconhecimento aparente, que este adquire por atuar em determinado lugar, como afirma Cláudia Lima Marques $^{101}$. O Tribunal de Justiça do Rio Grande do Sul entendeu que:

RESPONSABILIDADE CIVIL. ERRO DE DIAGNÓSTICO. LEGITIMIDADE PASSIVA DO MANTENEDOR DO COMPLEXO HOSPITALAR. DANOS MORAIS E MATERIAIS. CULPA. AUSÊNCIA DE PROVA. DEMANDA IMPROCEDENTE. 1 - O órgão mantenedor de o complexo hospitalar é parte legítima para ocupar o pólo passivo na ação de reparação dos danos, sofridos por paciente que alega erro de diagnóstico médico. Profissional médico que mantém vínculo de preposição ou integra a estrutura hospitalar. Preliminar de ilegitimidade afastada $^{102}$.

\footnotetext{
${ }^{99}$ STOCO, Rui. Iatrogenia e Responsabilidade civil do médico. Revista dos Tribunais. Ano 90, vol. 784, fev de 2001. Revista dos Tribunais, p. 110.

${ }^{100}$ CUNHA GONÇALVES, Luiz da. Tratado de Direito Civil. São Paulo: Max Limonad, v. 12, t. II, 1957, p. 965 apud KFOUFI NETO, Miguel. Responsabilidade do Médico. 6. ed. rev., atual e ampl. São Paulo: Revista dos Tribunais, 2007, p. 88.

${ }^{101}$ MARQUES, Cláudia Lima. A responsabilidade dos médicos e do hospital por falha no dever de informar ao consumidor. Revista dos Tribunais, ano 93, volume 827, set. 2004, p. 42.

${ }^{102}$ Tribunal de Justiça do Estado do Rio Grande do Sul. Apelação Cível No 70002015618 , Relator: Paulo Antônio Kretzmann, Décima Câmara Cível, Julgado em 04/10/2001.
} 


\subsection{Responsabilidade da equipe cirúrgica e erro anestésico}

Sérgio Cavalieri ${ }^{103}$ afirma que com o aprimoramento das especialidades médicas, tornou-se possível visualizar nitidamente as diversas funções, devendo, neste sentido, cada médico responder pelos seus próprios atos, o que não ocorre em caso de sociedade ou formação de uma equipe médica.

Sobre esse assunto, uma questão que deve ser levantada é a responsabilidade da equipe cirúrgica. Alguns autores entendem, como Carlos Roberto Gonçalves ${ }^{104}$, que a responsabilidade deva ser do médico-chefe, tendo em vista que os demais são apenas auxiliares e estão, sobretudo, sob suas ordens.

Assim, como pode ser observado, cabe ao anestesista, antes do procedimento cirúrgico, realizar exames a fim de verificar se o paciente tem intolerância ou é alérgico a algum medicamento, e fornecer todas as informações necessárias para que não seja surpreendido com alguma conseqüência inesperada após o momento operatório. Em caso de descumprimento ou dano, o médico será responsabilizado solidariamente, é o que entende o Superior Tribunal de Justiça:

Civil - Ação de indenização - Erro médico - Responsabilidade solidária do cirurgião (culpa in eligendo) e do anestesista reconhecida pelo acórdão recorrido. Matéria de prova. Súm. 7/STJ.

I - O médico chefe é quem se presume responsável, em princípio, pelos danos ocorridos em cirurgia, pois, no comando dos trabalhos, sob suas ordens é que executam-se os atos necessários ao bom desempenho da intervenção.

II - Da avaliação fática resultou comprovada a responsabilidade solidária do cirurgião (quanto ao aspecto 'in eligendo') e do anestesista pelo dano causado. Insuscetível de revisão esta matéria a teor do enunciado na Súm. 7/STJ.

III - Recurso não conhecido. ${ }^{105}$

Com relação a esse tema, José de Aguiar Dias ${ }^{106}$ afirma que nos casos em que há uma relação de subordinação, deve-se aplicar o entendimento do art. 932, III do Código Civil e estabelecer o âmbito da decisão do subordinado e do superior para que seja estabelecida a responsabilidade. Assim, se o subordinado só cumpre as ordens estipuladas pelo superior, a

${ }^{103}$ CAVALIERI FILHO, Sérgio. Programa de Responsabilidade Civil. 7. ed. São Paulo: Atlas, 2007, p.364.

${ }^{104}$ GONÇALVES, Carlos Roberto. Direito Civil Brasileiro, vol. IV. São Paulo: Saraiva, 2007, p. 240.

105 Superior Tribunal de Justiça, Resp. 53.104, Rel. Min. Waldemar Zveiter, Terceira Turma, Julgado em 04/03/97.

${ }^{106}$ DIAS, José de Aguiar. Da responsabilidade civil. 11. ed. Rio de janeiro: Renovar, 2006, p. 358-359. 
este deve incidir o dever de reparação, mas, sobretudo, se concorrem para a decisão, os dois devem ser responsabilizados solidariamente.

Portanto, no julgado acima transcrito, ficou constatada a responsabilidade solidária do cirurgião, mas nada impede que nos casos em que se verifique a culpa exclusiva do anestesista, a este cabe responder pelos danos causados ao paciente. O Tribunal de Justiça do Rio Grande do Sul entendeu que:

RESPONSABILIDADE CIVIL. MÉDICO ANESTESISTA. OMISSÃO. CULPA CARACTERIZADA. MORTE DO PACIENTE. DANOS MORAIS. QUANTUM. MANUTENÇÃO. PENSIONAMENTO. 1. Culpa. Médico anestesista que não apenas deixou de realizar o procedimento pré-anestésico, de sorte a apurar eventuais reações adversas do paciente, como também não agiu prontamente no atendimento do paciente, de modo a reverter o quadro de agitação apresentado e que culminou com a bradicardia, que logo acarretou a parada cardio-respiratória. Urgência não caracterizada. Criança submetida à intervenção cirúrgica em razão de um simples corte na mão, e que veio a falecer $(. . .)^{107}$.

${ }^{107}$ Tribunal de Justiça do Rio Grande do Sul, Apelação e Reexame Necessário No 70013347943, Relator: Paulo Antônio Kretzmann, Décima Câmara Cível, Julgado em 22/11/2007. 


\section{CAPÍTULO 3 - RESPONSABILIDADE CIVIL NAS CIRURGIAS PLÁSTICAS ESTÉTICAS}

\subsection{A atividade cirúrgica}

A atividade cirúrgica nasceu com a finalidade de corrigir alguma irregularidade física congênita ou traumática. Assim, pessoas que sofriam algum acidente, o que as deixavam com deformações externas, ou, ainda, pessoas que nasciam com alguma irregularidade ou defeito físico, geralmente, procuravam estas cirurgias, como no caso da Primeira Guerra Mundial (1914-1918), em que os feridos procuravam corrigir e recuperar os ferimentos adquiridos na guerra através da cirurgia plástica. É o que denominamos de cirurgia plástica reparadora.

A partir do início do século XX, a procura pela cirurgia plástica, não se deu apenas em função de uma reparação ou cura de uma enfermidade, visto que, as pessoas visavam melhorar a aparência física, ou seja, eliminar algumas imperfeições. Nesses casos, estamos diante de uma cirurgia plástica estética, em que o paciente está muito bem de saúde, mas procura o médico para corrigir um defeito estético externo, como o nariz, os seios, o abdômen, em decorrência do padrão de beleza imposto pela sociedade

Miguel Kfouri Neto ${ }^{108}$, em sua obra, também, distingue a cirurgia plástica estética propriamente dita e a cirurgia estética reparadora, sendo que para o referido autor, aquela pode ser subdivida em cirurgia de caráter estritamente estético e a cirurgia estética latu sensu.

$\mathrm{Na}$ cirurgia de caráter estritamente estético, o paciente é exposto a um grau elevado de risco e o médico tem a obrigação de atingir o resultado esperado, caso contrário, deverá ser responsabilizado. Há uma presunção de culpa e o médico só não responderá, se conseguir demonstrar a superveniência de um caso fortuito. Já na cirurgia plástica latu sensu, a obrigação é de meio e o risco a que se submete o paciente é pequeno. Esta cirurgia tem como finalidade corrigir pequenas deformidades do corpo humano, melhorando a aparência e a auto-estima.

A cirurgia plástica estética, no início, sofreu muitas restrições, mas com o passar dos tempos, o Conselho Federal de Medicina e a Sociedade de Cirurgia Plástica equiparam a cirurgia plástica reparadora com a estética, na medida em que a saúde não está relacionada

\footnotetext{
${ }^{108}$ KFOURI NETO, Miguel. Responsabilidade do Médico. 6. ed. rev., atual e ampl. São Paulo: Revista dos Tribunais, 2007, p. 182-183.
} 
apenas ao bem-estar e sim, psíquico e social. Assim, o Código de Ética da Associação Médica Brasileira $^{109}$, no seu art. 51 dispõe que:

Artigo $51^{\circ}$ - São licitas as intervenções cirúrgicas com finalidade estética, desde que necessárias ou quando o defeito a ser removido ou atenuado seja fator de desajustamento psíquico.

Neste mesmo sentido, o Conselho Regional de Medicina do Estado de São Paulo (CREMESP), na Resolução 81/97 estabeleceu que:

CONSIDERANDO que a Cirurgia Plástica é especialidade médica, reconhecida pelo Conselho Federal de Medicina e pela Associação Médica Brasileira, sem incorrer em subdivisões topográficas, diagnósticas ou de finalidade;

CONSIDERANDO que a Cirurgia Plástica tem seu conjunto de conhecimento regulamentado no ensino de graduação, na pós-graduação "lato sensu" (residência e especialização) e na pós graduação "stricto sensu" (mestrado e doutorado);

CONSIDERANDO que a Cirurgia Plástica tem sua prática profissional, regulamentada pelo Conselho Federal de Medicina, registrando o título de especialista, obtido pela Residência-Médica, credenciada pela Comissão Nacional de Residência-Médica e através da Sociedade Brasileira de Cirurgia Plástica;

CONSIDERANDO que a Cirurgia Plástica trata de doenças e deformidades congênitas, adquiridas, traumáticas, degenerativas e oncológicas, assim como de suas conseqüências, visando beneficiar os pacientes, do ponto de vista funcional, psicológico e social objetivando a melhoria da qualidade de vida;

CONSIDERANDO a necessidade de informar a Sociedade Civil da real função da Cirurgia Plástica, como especialidade médica;

CONSIDERANDO, finalmente, o decidido, na Sessão Plenária, realizada em 03/06/97.

RESOLVE:

Artigo $1^{\circ}$ - A Cirurgia Plástica é especialidade única, indivisível e, como tal, deve ser exercida por médicos devidamente qualificados, utilizando técnicas habituais, reconhecidas cientificamente.

Com relação a esse assunto, Miguel Kfouri afirma que "enfermidade não é apenas o processo patológico de degeneração orgânica ou física. Existe uma variada gama de moléstias mentais e de perturbações psíquicas. A cirurgia estética pode atenuar ou eliminar totalmente um mal-estar, não físico, mas psíquico ou moral". ${ }^{110}$ Verificamos que a pessoa que procura a cirurgia plástica visa superar alguma dificuldade ou problema físico, que a incomoda e a faz sofrer.

\footnotetext{
${ }^{109}$ Aprovado na IV Reunião do Conselho Deliberativo, ocorrida no Rio de Janeiro no dia 30 de janeiro de 1953 e reconhecido pela Lei $\mathrm{n}^{\circ} 3.268$ de 30 de setembro de 1957.

${ }^{110}$ KFOURI NETO, Miguel. Responsabilidade do Médico. 6. ed. rev., atual e ampl. São Paulo: Revista dos Tribunais, 2007, p. 180.
} 
Com relação a essa finalidade da cirurgia plástica estética, Silvio de Salvo Venosa entende que:

\begin{abstract}
(...) o desajuste psíquico é conceito dúctil. O médico deve ser convenientemente responsável no aconselhar ou desaconselhar cirurgia plástica estética. Um aleijão no rosto de uma jovem causa evidente problema psíquico. Uma cicatriz em musculoso lutador de boxe poderá não sê-lo. O caso concreto dará a solução ${ }^{111}$.
\end{abstract}

Assim, a cirurgia plástica estética é hoje vista no Brasil como um grande viés de auto-estima e beleza e, assim, o país é o segundo que mais realiza esse tipo de cirurgia, ficando atrás apenas dos EUA. As cirurgias plásticas estéticas mais procuradas são: mamoplastia (cirurgia de correção de mamas); lipoaspiração (eliminação de excesso de gordura corporal localizada); rinoplastia (reparação no nariz); otoplastia (correção nas orelhas) e; por fim, ritidoplastia (eliminação de rugas faciais).

Para o planejamento de uma cirurgia plástica estética é fundamental a análise de condições físicas, clínicas e psicológicas. Assim, sobretudo, a atitude psíquica de um paciente não pode ser deixada de lado, na medida em que a procura pela cirurgia é feita na esperança que ocorra uma performance corretiva das deformidades corporais que este paciente acredita ser possuidor.

Esta cirurgia plástica estética não tem urgência e o paciente não terá nenhuma conseqüência caso ela não seja realizada e, por esta razão, cabe ao médico informar adequadamente todos os riscos por mais que seja raros, deixar bem claro qual será o procedimento e, por fim, explicitar como o paciente deverá agir após o tratamento.

\title{
3.2 Lex Artis ad hoc
}

Miguel Kfouri Neto define a Lex Artis ad hoc como: "critério valorativo da correção do ato concretizado pelo profissional da medicina - arte ou Ciência Médica visando a verificar se a atuação é compatível - ou não - com o acervo de exigências e a

\footnotetext{
${ }^{111}$ VENOSA, Silvio de Salvo. Direito Civil: Responsabilidade Civil, 2. ed., v. 4., São Paulo: Atlas, 2002 , p. 95.
} 
técnica normalmente requerida para determinado ato, observando-se a eficácia dos serviços prestados e a possível responsabilidade do médico/autor pelo resultado obtido". ${ }^{112}$

As profissões são regidas por uma Lex Artis, mas no caso do médico, ela deve ser vista de forma individual, levando em consideração os aspectos intrínsecos do profissional de medicina e os recursos disponíveis para a realização do tratamento. Assim, cabe ao juiz utilizar informações do perito, de assistentes técnicos e a própria doutrina médica para julgar o ato médico lesivo.

\subsection{Cirurgia Plástica Estética: Obrigação de Meio ou de Resultado}

A obrigação do médico é objeto de diversos questionamentos. Durante a vigência do Código Civil de 1916, para que o médico fosse responsabilizado era necessária a prova da culpa, como pode ser observado no art. 1545: "Os médicos, cirurgiões, farmacêuticos, parteiras e dentistas são obrigados a satisfazer o dano, sempre que da imprudência, negligência, ou imperícia, em atos profissionais, resultar morte, inabilitação de servir ou ferimento".

A partir da elaboração do Código de Defesa do Consumidor e do avanço da medicina, alguns doutrinadores conduziram a responsabilidade do médico cirurgião plástico como uma obrigação de resultado, no qual se espera que seja atingido determinado fim assumido contratualmente.

Assim, na obrigação de meio, o médico deve apenas agir com cautela, atenção, prudência, utilizar todas as regras, técnicas da sua profissão e as experiências adquiras ao longo dos anos, não sendo necessário que atinja o resultado esperado. Assim, para que surja o dever de indenizar, cabe ao paciente, a vítima, provar que o médico agiu sem a diligência exigível para a realização do tratamento, caso contrário, o pedido será improcedente, visto que o médico não está vinculado a uma obrigação de resultado.

Já na obrigação de resultado, o médico assume a obrigação de atingir o resultado almejado pelo paciente através de um contrato e, por esta razão, caso verifique que esse fim não é possível, ou ainda, o perigo da intervenção é maior que a vantagem proporcionada, caberá ao médico informar ao paciente e se negar a realizá-lo. Neste sentido, entendemos que:

112 KFOURI NETO, Miguel. Responsabilidade do Médico. 6. ed. rev., atual e ampl. São Paulo: Revista dos Tribunais, 2007, p. 177. 
Busca-se o necessário controle e a urgente limitação das cirurgias estéticas, cuja realização só deve ser contratada quando o médico, após rigorosa avaliação clínica, constatar que o benefício buscado ou o embelezamento pretendido não colocará em risco substancial a vida de paciente saudável ${ }^{113}$.

Portanto, caso o médico não consiga alcançar o resultado esperado pelo paciente de acordo com o estabelecido no contrato pelas partes, poderá ser impetrado uma ação de indenização, pela vítima, abrangendo as despesas, danos morais, e verbas para tratamento ou uma nova cirurgia, segundo Carlos Roberto Gonçalves ${ }^{114}$, independentemente de apuração de culpa.

$\mathrm{Na}$ obrigação de resultado, assim, a responsabilidade é subjetiva, mas a culpa é presumida, como salienta Sérgio Cavalieri Filho ${ }^{115}$ e, para outros, a responsabilidade é objetiva, como entende Alexandre Gir Gomes ${ }^{116}$. Independentemente da denominação, até porque, nos dois casos, se prescinde a verificação da culpa, e há uma inversão do ônus da prova, cabendo ao médico, para se ver livre dessa obrigação de indenização, demonstrar sua conduta diligente e a existência de alguma excludente de responsabilidade, como já foi visto.

A jurisprudência francesa entende que o médico deve responder pela conduta danosa independentemente do reconhecimento de culpa, na medida em que se está diante de uma cirurgia desnecessária, de acordo com Kfouri Neto ${ }^{117}$. E Introna, na Itália, afirma, segundo Miguel Kfouri Neto, que:

O simples fato de haver empreendido sobre uma região corporal sadia uma operação que comporta riscos de real gravidade, com o único objetivo de corrigir o aspecto exterior, é suficiente a concretizar uma culpa fora daqueles que são os habituais requisitos da responsabilidade profissional $^{118}$.

No Brasil, alguns doutrinadores entendem que a obrigação do médico cirurgião plástico é de meio e não de resultado, na medida em que não se deve imputar a

113 GIR GOMES, Alexandre. Responsabilidade civil do médico nas cirurgias plásticas estética. Revista de direito Privado, ano 3, out.-dez. de 2002, p. 90.

${ }^{114}$ GONÇALVES, Carlos Roberto. Direito Civil Brasileiro, vol. IV. São Paulo: Saraiva, 2007, p. 245.

${ }^{115}$ CAVALIERI FILHO, Sérgio. Programa de Responsabilidade Civil. 7. ed. São Paulo: Atlas, 2007, p. 370.

116 GIR GOMES, Alexandre. Responsabilidade civil do médico nas cirurgias plásticas estética. Revista de Direito Privado, ano 3, out.-dez. de 2002, p. 88.

117 KFOURI NETO, Miguel. Responsabilidade do Médico. 6. ed. rev., atual e ampl. São Paulo: Revista dos Tribunais, 2007, p. 171.

118 INTRONA, F. La responsabilitá professionale nell esercizio delle arti sanitare, p. 223 apud KFOURI NETO, Miguel. Op. cit., p. 171. 
responsabilidade aos médicos, em caso de insucesso cirúrgico, quando se tratar de circunstâncias imprevisíveis, caso contrário, estar-se-á exigindo do médico um poder “extrasensorial de prever o desenlace da própria vida" 119.

Quanto à expectativa de um resultado, a Resolução 81/97 do Conselho Regional de Medicina do Estado de São Paulo (CREMESP), estabeleceu no seu art. $4^{\circ}$ que:

Art. 4 - Na Cirurgia Plástica, como em qualquer especialidade médica, o médico não deve prometer resultado ou garantia do tratamento. O médico deverá informar ao paciente, de forma clara, sobre os benefícios e riscos do procedimento.

Neste mesmo sentido, Rosane Jane Magrini ${ }^{120}$, ao citar Rui Stoco $^{121}$ afirma que na cirurgia plástica, o paciente se submete aos mesmos riscos que qualquer outra cirurgia e, por esta razão, nada impede que o paciente seja surpreendido com um resultado indesejável, em razão de características peculiares ${ }^{122}$ do próprio paciente, o que justifica a obrigação de meio. Portanto, o médico não deverá ser responsabilizado por qualquer resultado indesejado, desde que tenha alertado ao paciente dos riscos da cirurgia e da possibilidade de ocorrência de um eventual dano.

O Min. Ruy Rosado Aguiar Jr., de acordo com Cavalieri, argumenta que a responsabilidade do cirurgião plástico em nada se diferencia dos demais médicos, visto que:

\footnotetext{
${ }^{119}$ MAGRINI, Rosana Jane Médico. Cirurgia plástica reparadora e estética: obrigação de meio ou de resultado para o cirurgião. Revista Jurídica, 280/77-93. São Paulo: Notadez, 2001, p. 91 apud MARTINS, Joana Graeff. Cirurgia Plástica Estética: natureza da obrigação do cirurgião. Revista de Direito Privado. Ano 10, n. 37, jan.mar./2009, p. 115.

${ }^{120}$ MAGRINI, Rosana Jane Médico. Cirurgia plástica reparadora e estética: obrigação de meio ou de resultado para o cirurgião. Revista Jurídica, 280/77-93. São Paulo: Notadez, 2001, p. 73-93 apud MARTINS, Joana Graeff. Cirurgia Plástica Estética: natureza da obrigação do cirurgião. Revista de Direito Privado. Ano 10, $\mathrm{n}$. 37, jan.-mar./2009, p. 114.

${ }^{121}$ STOCO, Rui. Responsabilidade civil e sua interpretação jurisprudencial. 4. ed. São Paulo: Revista dos Tribunais, 1999, p. 286 apud MARTINS, Joana Graeff. Op. cit., p. 114 .

${ }^{122}$ As características individuais do ser humano que podem influenciar o resultado são: "1 - raça de origem: o tipo de pele dos indivíduos de raça negra e amarela é mais suscetível de manifestar cicatrizes hipertróficas do que a dos caucasianos; 2 - hereditariedade: embora os estudos ainda não sejam conclusivos, existem alguns grupos de indivíduos com o acometimento severo e história familiar positiva no aparecimento de quelóides; 3 idade: em um mesmo indivíduo, a tendência ao quelóide pode estar presente em uma certa idade e, posteriormente, ficar atenuada ou desaparecer; 4 - fatores locais: as regiões mais propensas à hipertrofia cicatricial são as peitorais, deltóides e face, sendo comum o surgimento de quelóides nas perfurações das orelhas. Mostra-se comuma coexistência numa mesma região, de quelóides e cicatrizes finas. Aliás, a mesma cicatriz pode apresentar segmentos normais e hipertróficos intercalados; 5 - tensões entre os bordos da ferida; 6 ocorrência de infecção local; 7 - suturas muito apertadas: hipótese em que podem surgir áreas de necrose."
} 
(...) corre os mesmos riscos e depende da mesma álea, endossa esse entendimento, tendo em vista que toda operação existe um risco ligado à reação do próprio organismo humano, tipo de pele extremamente sensível, infecção hospital, etc., situações muitas vezes imprevisíveis e que não podem ser imputadas ao médico. A eventual falta de informação precisa sobre o risco, e a não-obtenção de consentimento plenamente esclarecido, arremata o ilustre Ministro, conduzirão à responsabilidade do cirurgião, mas por descumprimento culposo da obrigação de meios (Responsabilidade Civil do Médico, RT 718/40) ${ }^{123}$.

Neste contexto, o cirurgião plástico Juarez Moraes Avelar ${ }^{124}$ entende que a cirurgia plástica estética é uma das especialidades da medicina e está exposta a reações do corpo humano que são inesperadas, como qualquer outra cirurgia, exemplo é a quelóide, que nada mais é do que uma cicatriz imprevisível.

Dentre estas circunstâncias imprevistas, que podem causar o surgimento de uma iatrogenia, Joana Graeff Martins cita a "rejeição, deficiência física, conduta inadequada do paciente, abandono de tratamento sem alta médica, reação metabólica, vida pregressa de fumo, atitude somato-psíquica, entre outros" ${ }^{125}$. Por esta razão, continua a advogada "ninguém pode se obrigar à realização plena de uma obrigação que, na maioria das vezes, está fora dos seus limites de atuação e deliberação em razão dos riscos ligados à reação do organismo" 126 .

Neste sentido, há um rompimento do nexo causal, como afirma Rosana Jane Magrini:

É que a intercorrência de fatores e reações que a ciência médica ainda desconhece, como o exemplo supracitado de formação de cicatriz queloidiana, a meu ver, rompe a cadeia causal, e, como se sabe, a força maior, o caso fortuito e a culpa exclusiva da vítima, como visto, são causas excludentes da responsabilidade civil. E os fatores aleatórios, repita-se, quebram o nexo entre a conduta médica e o resultado ${ }^{127}$.

${ }^{123}$ CAVALIERI FILHO, Sérgio. Programa de Responsabilidade Civil. 7. ed. São Paulo: Atlas, 2007, p. 369.

124 AVElAR, Juarez Moraes. Cirurgia Plástica: Obrigação de meio. São Paulo: Hipócrates, 2000 apud GONÇALVES, Carlos Roberto. Direito Civil Brasileiro. vol. IV. São Paulo: Saraiva, 2007, p. 245.

${ }^{125}$ MARTINS, Joana Graeff. Cirurgia Plástica Estética: natureza da obrigação do cirurgião. Revista de Direito Privado. Ano 10, n. 37, Revista dos Tribunais, jan.-mar./2009, p. 117.

${ }^{126}$ MARTINS, Joana Graeff. Op. cit., p. 118.

${ }^{127}$ MAGRINI, Rosana Jane. Médico. Conduta. Teoria da imprevisão. Caso fortuito. Força maior. Nexo causal: em matéria de responsabilidade, o exame da conduta do médico deve ser aferido com flexibilidade. Revista dos Tribunais, ano 89, vol. 781, Nov. de 2000, p. 140. 
Assim, alguns doutrinadores como Ruy Rosado, Vera Fradera, Luis O. Andorno, Rosana Jane Magrini, Miguel Kfouri entendem que a responsabilidade deve ser de meio, na medida em que por mais que eles prometam atingir determinado resultado e apliquem todas as técnicas da medicina com cautela e prudência, pode-se advir consequências indesejáveis em razão de reações inesperadas do próprio paciente. Miguel Kfouri Neto afirma que:

\begin{abstract}
Em qualquer hipótese, não milita, em favor do cirurgião plástico, nessas intervenções embelezadoras, presunção de culpa, nem tampouco se aplicam os princípios da responsabilidade sem culpa. Por fim, as novas tendências verificadas no âmbito da prova da culpa médica, em especial a atribuição dinâmica do encargo probatório, não mais justificam que apenas ao cirurgião plástico seja aplicado tratamento diferenciado, gravoso. Todas as especialidades cirúrgicas submetem-se ao imprevisível - conseqüência natural, já examinada, das características individuais de cada pessoa. Assim, a cirurgia plástica embelezadora há de enquadrar no figurino da verificação da culpa, a exemplo das demais especialidades médicas - arredando-se a aplicação extremada dos princípios da responsabilidade objetiva ao profissional liberal, que também se submete ao estatuto da culpa ${ }^{128}$.
\end{abstract}

Além disso, o próprio Conselho Regional de Medicina do Estado de São Paulo (CREMESP), na Resolução 81/97 dispõe no art. $5^{\circ}$ que:

Art. 5 - O objetivo do ato médico, na Cirurgia Plástica, como em toda a prática médica, constitui obrigação de meio e não obrigação de fim ou de resultado.

Portanto, alguns autores reconhecem que a obrigação dos médicos cirurgiões plásticos é de meio, na medida em que por mais que alguns profissionais de medicina assegurem a obtenção do resultado esperado pela vítima, não se deve alterar a natureza da obrigação. No entanto, como se tem visto, os Tribunais, em muitos casos, não seguem, em sua maioria, essa interpretação.

Neste mesmo sentido, Aguiar Dias, Sílvio Rodrigues, Caio Mário, Genival Veloso de França, Teresa Ancona Lopes, Calos Roberto Gonçalves, Sérgio Cavalieri, dentre outros, defendem o posicionamento de que a responsabilidade do cirurgião estético é de resultado em razão da finalidade a que se propusera no momento da cirurgia.

${ }^{128}$ KFOURI NETO, Miguel. Responsabilidade do Médico. 6. ed. rev., atual e ampl. São Paulo: Revista dos Tribunais, 2007, p. 267. 
Para esses autores, por mais que o médico cirurgião plástico tenha aplicado todas as técnicas com sucesso e não consegue atingir o resultado esperado em razão de características do próprio paciente, não se deve afastar a responsabilidade de resultado do médico, segundo os ensinamentos de Sérgio Cavalieri ${ }^{129}$. No entanto, fatores imprevisíveis e inesperados podem romper o nexo causal e, consequentemente, fazer com que o médico não seja obrigado a reparar o dano.

A obrigação de resultado para os cirurgiões plásticos estéticos se dá porque: "ninguém se submete a uma operação plástica se não for para obter um determinado resultado, isto é, a melhoria de uma situação que pode ser, até aquele momento, motivo de tristezas" ${ }^{130}$, de acordo com Tereza Ancona Lopes, ou seja, na cirurgia plástica estética, busca-se atingir um determinado resultado, como o embelezamento, e não apenas que o médico desempenhe sua atividade com diligência.

Essa busca incessante pelo resultado se dá muitas vezes porque o próprio médico, através de anúncios, se compromete a obter o que o paciente está procurando, como um corpo perfeito ou uma aparência jovial. Assim, Rui Stoco afirma que:

\begin{abstract}
O que impede considerar é que o profissional na área de cirurgia plástica, nos dias atuais, promete um determinado resultado (aliás, essa é a sua atividade-fim), prevendo, inclusive com detalhes, esse novo resultado estético procurado. Alguns utilizam-se mesmo de programas de computador que projetam a nova imagem (nariz, boca, olhos, seios, nádegas etc.), através de montagem, escolhida na tela do computador ou na impressora, para que o cliente decida. Estabelece-se, sem dúvida, entre médico e paciente relação contratual de resultado que deve ser honrada ${ }^{131}$.
\end{abstract}

Silvio Rodrigues afirma que a busca na cirurgia plástica estética "é um fim em si mesmo, tal como uma nova conformação do nariz, a supressão de rugas, a remodelação das pernas, seios, queixo etc. De modo que o paciente espera do cirurgião, não que se empenhe em conseguir um resultado, mas que obtenha o resultado em si” ${ }^{132}$, até porque, por ser um procedimento facultativo, caso o médico acredite que não conseguirá atingir o resultado esperado pelo paciente, caberá a ele se abster do procedimento cirúrgico.

\footnotetext{
${ }^{129}$ CAVALIERI FILHO, Sérgio. Programa de Responsabilidade Civil. 7. ed. São Paulo: Atlas, 2007, p. 370.

${ }^{130}$ LOPES, Teresa Ancona. O dano estético: responsabilidade civil. 3. ed. rev . e atual. São Paulo: Revista dos Tribunais, 2004, p. 120.

131 STOCO, Rui. Responsabilidade civil e sua interpretação jurisprudencial. 4 ed. São Paulo: Revista dos Tribunais, 1999, p. 298-299.

${ }^{132}$ RODRIGUES, Silvio. Direito civil - Responsabilidade Civil. v. 4., 20. ed. São Paulo: Saraiva, 2003, p. 252.
} 
Assim, o Superior Tribunal de Justiça entendeu que:

\begin{abstract}
“CIVIL E PROCESSUAL - CIRURGIA ESTÉTICA OU PLÁSTICA OBRIGAÇÃO DE RESULTADO (RESPONSABILIDADE CONTRATUAL OU OBJETIVA) - INDENIZAÇÃO - INVERSÃO DO ÔNUS DA PROVA.

I - Contratada a realização da cirurgia estética embelezadora, o cirurgião assume obrigação de resultado (Responsabilidade contratual ou objetiva), devendo indenizar pelo não cumprimento da mesma, decorrente de eventual deformidade ou de alguma irregularidade.

II - Cabível a inversão do ônus da prova.

III - Recurso conhecido e provido ${ }^{133}$
\end{abstract}

E em outro julgado afirma que:

CIVIL. PROCESSUAL CIVIL. RECURSO ESPECIAL. RESPONSABILIDADE CIVIL. NULIDADE DOS ACÓRDÃOS PROFERIDOS EM SEDE DE EMBARGOS DE DECLARAÇÃO NÃO CONFIGURADA. CIRURGIA PLÁSTICA ESTÉTICA. OBRIGAÇÃO DE RESULTADO. DANO COMPROVADO. PRESUNÇÃO DE CULPA DO MÉDICO NÃO AFASTADA. PRECEDENTES.

1. Não há falar em nulidade de acórdão exarado em sede de embargos de declaração que, nos estreitos limites em que proposta a controvérsia, assevera inexistente omissão do aresto embargado, acerca da especificação da modalidade culposa imputada ao demandado, porquanto assentado na tese de que presumida a culpa do cirurgião plástico em decorrência do insucesso de cirurgia plástica meramente estética.

2. A obrigação assumida pelo médico, normalmente, é obrigação de meios, posto que objeto do contrato estabelecido com o paciente não é a cura assegurada, mas sim o compromisso do profissional no sentido de um prestação de cuidados precisos e em consonância com a ciência médica na busca pela cura.

3. Apesar de abalizada doutrina em sentido contrário, este Superior Tribunal de Justiça tem entendido que a situação é distinta, todavia, quando o médico se compromete com o paciente a alcançar um determinado resultado, o que ocorre no caso da cirurgia plástica meramente estética. Nesta hipótese, segundo o entendimento nesta Corte Superior, o que se tem é uma obrigação de resultados e não de meios.

4. No caso das obrigações de meio, à vítima incumbe, mais do que demonstrar o dano, provar que este decorreu de culpa por parte do médico. Já nas obrigações de resultado, como a que serviu de origem à controvérsia, basta que a vítima demonstre, como fez, o dano (que o médico não alcançou o resultado prometido e contratado) para que a culpa se presuma, havendo, destarte, a inversão do ônus da prova.

5. Não se priva, assim, o médico da possibilidade de demonstrar, pelos meios de prova admissíveis, que o evento danoso tenha decorrido, por exemplo, de motivo de força maior, caso fortuito ou mesmo de culpa exclusiva da "vítima" (paciente).

6. Recurso especial a que se nega provimento ${ }^{134}$.

133 Superior Tribunal de Justiça. Resp 81101/PR. Ministro Waldemar Zveiter. Terceira Turma. Julgado em 13/04/1999.

${ }^{134}$ Superior Tribunal de Justiça. Resp 236708/MG. Ministro Carlos Fernando Mathias. Quarta Turma. Julgado em 10/02/2009. 
Além disso, para Sérgio Cavalieri ${ }^{135}$, essa responsabilidade continua sendo subjetiva, face à responsabilidade civil estabelecida pelo Código de Defesa do Consumidor. Neste caso, ocorre uma inversão do ônus da prova quanto à culpa, na medida em que quando: se tratar de responsabilidade do médico em cirurgias plásticas estéticas, a culpa será presumida e só será afastada mediante prova de ocorrência de uma das excludentes da responsabilidade ou quando o dano decorreu de reações do próprio paciente, que mesmo sabendo dos riscos, consentiu a cirurgia, como afirma Ênio Santarelli Zuliani ${ }^{136}$.

No entanto, não podemos deixar de mencionar que essa obrigação de resultado não atinge as cirurgias plásticas reparadoras, em que o paciente visa corrigir deformidades decorrentes de traumas, como uma cirurgia mal sucedida, ou queimaduras, como pode ser observado no julgado do Tribunal de Justiça de Minas Gerais:

RESPONSABILIDADE CIVIL - INDENIZAÇÃO - DANOS MORAIS E ESTÉTICOS - ERRO MÉDICO - CIRURGIA REPARADORA - OBRIGAÇÃO DE MEIO - CULPA - ÔNUS DA PROVA - As cirurgias reparadoras, ao contrário das cirurgias estéticas, são 'obrigação de meio' e não de resultado. - Em sendo a cirurgia reparadora e, portanto, tratando-se de obrigação de meio, para a responsabilização do médico por dano causado à paciente, faz-se necessário que resulte devidamente comprovado que o evento danoso se deu em razão de negligência, imprudência, imperícia $^{137}$.

Assim, quando for verificar a obrigação do médico, é preciso distinguir a cirurgia plástica estética da cirurgia plástica reparadora, na medida em que o médico, nesta segunda modalidade de cirurgia, "nem sempre pode prometer a eliminá-la, porém, realizar o que seja melhor" ${ }^{138}$, como afirma Caio Mário da Silva Pereira, na medida em que se está diante de uma obrigação de meio e não de resultado.

\footnotetext{
${ }^{135}$ CAVALIERI FILHO, Sérgio. Programa de Responsabilidade Civil. 7. ed. São Paulo: Atlas, 2007, p.370.

136 ZULIANI, Ênio Santarelli. Responsabilidade Civil Fundada em erro Médico: Inversão do Ônus da Prova. Revista Síntese de Direito Civil e Processual Civil, ano V, nº 26, nov.-dez. 2003, p. 142.

${ }^{137}$ Tribunal de Justiça do Estado de Minas Gerais. Processo n ${ }^{\circ}$ 2.0000.00.489717-8/000. Relatora: Hilda Teixeira da Costa. Julgado em 18/08/2005.

138 PEREIRA, Caio Mário da Silva. Responsabilidade médica. Seleções Jurídicas ADV, v. 2, p. 10 apud ZULIANI, Ênio Santarelli Zuliani. Responsabilidade Civil Fundada em erro Médico: Inversão do Ônus da Prova. Revista Síntese de Direito Civil e Processual Civil, ano V, nº 26, nov.-dez. 2003, p. 142.
} 


\section{Conclusão}

Um dos princípios da Constituição Federal é assegurar a todos, os direitos fundamentais, ou seja, os direitos mais elementares, necessários à garantia da dignidade da pessoa humana, tais como: a igualdade, a liberdade, a solidariedade e, por fim, a integridade física e moral. Assim, cabe ao Estado intervir, quando necessário, para que esses princípios sejam respeitados por todos.

Além disso, de um lado temos o avanço da ciência médica que ocasionou um crescimento dos recursos à disposição do profissional, aumentando as chances de cura e, consequentemente os riscos também. De outro lado, verificamos a falta de preparo dos médicos em razão do crescimento desordenado das escolas de medicina.

Os usuários dos serviços médicos estão cada vez mais atentos aos seus direitos e cientes de que no caso de erro inescusável como negligência, imprudência e imperícia, cabe uma ação de reparação. A aferição do elemento culpa é imprescindível para que gere a obrigação de indenizar, por mais que em alguns casos seja difícil provar o nexo causal entre a conduta culposa do médico e o dano. Diante dessa assertiva, o legislador permitiu a inversão do ônus da prova, quando necessário, de acordo com o art. $6^{\circ}$, VIII do Código de Defesa do Consumidor.

A responsabilidade médica nas cirurgias plásticas tem uma grande relevância na sociedade e no mundo jurídico, visto que, como pode ser observado, estas cirurgias estão cada vez mais acessíveis e procuradas, em função, principalmente, da satisfação com a própria aparência.

No entanto, não se deve responsabilizar os profissionais de medicina por qualquer dano, principalmente quando nos referimos a riscos atinentes ao próprio ser humano.

Os médicos em geral, assim como o cirurgião plástico que visa reparar uma lesão ou deformidade que o paciente já possuía, estão vinculados a uma obrigação de meio e, portanto, não serão responsabilizados caso não venham a atingir um determinado resultado esperado pelo paciente.

Nesses casos, basta ao profissional de medicina, a fim de se eximir da obrigação de indenizar, informar exaustivamente o tratamento a ser empregado e os possíveis ricos que poderão advir da intervenção cirúrgica, bem como realizar o tratamento de acordo com as 
técnicas e regras aplicáveis ao caso, e por fim, acompanhar o paciente durante o pósoperatório.

Entretanto, no caso das cirurgias plásticas estéticas, conforme demonstrado no presente estudo, há uma discussão, entre os doutrinadores, de qual seria a natureza da obrigação, se de meio ou de resultado. No primeiro caso, para que o médico tenha o dever de indenizar o paciente, faz-se necessária a prova de culpa, ou seja, de que o médico agiu com imprudência, negligência ou imperícia, já na obrigação de resultado, a culpa é presumida e, por esta razão, basta ao paciente demonstrar o dano e o nexo causal.

Como já salientado, independentemente da obrigação, cabe ao médico agir com cuidado e prudência, realizar os exames pré-operatórios, esclarecer todas as dúvidas do paciente, aconselhar no caso de diferentes possibilidades de tratamento, obter o consentimento informado adequadamente e se negar a realizar a cirurgia plástica, caso entenda como sendo uma intervenção cirúrgica inadequada. Além disso, o médico não deve prometer e, muito menos, pactuar, um resultado perfeito, tendo em vista que poderão advir consequiências adversas inesperadas e imprevisíveis em razão de características peculiares do próprio ser humano.

O médico, neste caso, deverá responder pelos danos causados, seja, material, moral ou estético, só se eximindo se for demonstrado o rompimento do nexo causal por uma das excludentes de responsabilidade, como: culpa exclusiva da vítima; caso fortuito e força maior; fato de terceiro; estado de necessidade; legítima defesa, exercício regular do direito e estrito cumprimento do dever legal, isso porque a responsabilização deve se dar em caso de erro médico ou, ainda, quando é omisso e não porque a sua categoria profissional está na seara da obrigação de resultado.

Assim, constata-se a complexidade da doutrina e da jurisprudência quanto à responsabilidade civil dos médicos nas cirurgias plásticas estéticas, em face dos contraditórios e, subjetividade das causas e efeitos. Esse fato se agrava pela amplitude atual dessa conflitante sociedade brasileira, em que a significativa demanda é estimulada por vaidades e ampla propaganda, muitas das vezes enganosas.

Neste sentido, cabe ao Conselho Regional de Medicina intervir quando os profissionais de medicina não atuam de acordo com a ética profissional e com o princípio da boa-fé, através da advertência reservada ou pública, suspensão do exercício da profissão e, por fim, a cassação do registro, quando necessária. 


\section{Referências Bibliográficas}

ALVIM, Agostinho. Da inexecução das obrigações e suas conseqüências. 3. ed. Jurídica e Universitária, n. 208.

CALIXTO, Marcelo Junqueira. A culpa na Responsabilidade Civil: estrutura e função. Rio de Janeiro: Renovar, 2008.

CAVALIERI FILHO, Sérgio. Programa de Responsabilidade Civil. 7. ed. São Paulo: Atlas, 2007.

COSTA, Mário Júlio de Almeida. Direito das Obrigações. 6. ed. Coimbra: Almedina, 1994.

DE PLÁCIDO E SILVA. Vocábulo jurídico.

DIAS, José de Aguiar. Da responsabilidade civil. 11. ed. Rio de janeiro: Renovar, 2006.

FACCHINI NETO, Eugênio. Da responsabilidade civil no novo Código In: SARLET, Ingo (Org.). O novo Código Civil e a Constituição. Porto Alegre: Livraria do Advogado, 2003.

GIR GOMES, Alexandre. Responsabilidade civil do médico nas cirurgias plásticas estética. Revista de direito Privado, ano 3, Revista dos Tribunais, out.-dez. de 2002.

GONÇALVES, Carlos Roberto. Direito Civil Brasileiro. vol. IV. São Paulo: Saraiva, 2007.

GRINOVER, Ada Pellegrini... [et al.]. Código de Defesa do Consumidor comentado pelos autores do anteprojeto. 8. ed. Rio de Janeiro: Forense Universitária, 2004.

KFOURI NETO, Miguel. Responsabilidade do Médico. 6. ed. rev., atual e ampl. São Paulo: Revista dos Tribunais, 2007.

LOPEZ, Teresa Ancona. $O$ dano estético: responsabilidade civil. 3. ed. rev . e atual. São Paulo: Revista dos Tribunais, 2004.

MAGRINI, Rosana Jane. Médico. Conduta. Teoria da imprevisão. Caso fortuito. Força maior. Nexo causal: em matéria de responsabilidade, o exame da conduta do médico deve ser aferido com flexibilidade. Revista dos Tribunais, ano 89, vol. 781, Nov. de 2000.

- Médico. Cirurgia plástica reparadora e estética: obrigação de meio ou de resultado para o cirurgião. Revista dos Tribunais, ano 92, vol. 809, mar. de 2003.

MARQUES, Cláudia Lima. A responsabilidade dos médicos e do hospital por falha no dever de informar ao consumidor. Revista dos Tribunais, ano 93, vol. 827, set. 2004. 
MARTINS, Joana Graeff. Cirurgia Plástica Estética: natureza da obrigação do cirurgião. Revista de Direito Privado. Ano 10, n. 37, jan.-mar./2009.

MARTINS COSTA, Judith. A boa-fé no Direito Privado. São Paulo: Revista dos Tribunais, 1999.

MIRAGEM, Bruno. Responsabilidade civil médica no Direito civil brasileiro. Revista de Direito do Consumidor. Ano 16, n. 63, jul.-set. 2007.

NASCIMENTO, Tupinambá. Responsabilidade Civil no Código de Defesa do Consumidor. Rio de janeiro: Aide, 1991.

OLIVEIRA MATOS, Eneas de. Dano Moral e Dano Estético. Rio de Janeiro: Renovar, 2008.

PRUX, Oscar Ivan. A Responsabilidade Civil do profissional liberal no Código de Defesa do Consumidor. Belo Horizonte: Del Rey, 2007.

RODRIGUES, Silvio. Direito Civil - Responsabilidade Civil. v. 4, 20. ed.. São Paulo: Saraiva, 2003.

SAMPAIO, Rogério Marrone de Castro. Direito civil: responsabilidade civil. São Paulo: Atlas S.A., 2000.

SILVA PEREIRA. Caio Mário. Instituições de Direito Civil. 3. ed. Rio de Janeiro: Forense, 1992.

STOCO, Rui. Iatrogenia e Responsabilidade civil do médico. Revista dos Tribunais. Ano 90, vol. 784, fev. de 2001.

STOCO, Rui. Responsabilidade civil e sua interpretação jurisprudencial: doutrina e jurisprudência. 4. ed., São Paulo: Revista dos Tribunais, 1999.

WEBER, Márcia Regina Lusa Cadore. Responsabilidade civil do médico. Revista de Direito Privado, ano 5, abr.-jun. de 2004.

ZULIANI. Ênio Santarelli. Responsabilidade Civil Fundada em erro Médico: Inversão do Ônus da Prova. Revista Síntese de Direito Civil e Processual Civil, ano V, n. 26, nov.-dez. 2003. 